\title{
International Peacebuilding: A Theoretical and Quantitative Analysis*
}

\author{
Michael W. Doyle (Princeton University, CIS) \\ Nicholas Sambanis (The World Bank, DECRG)
}

August 22, 2000

Copyright by the American Political Science Association

\begin{abstract}
International peacebuilding can improve the prospects that a civil war will be resolved. Although peacebuilding strategies must be designed to address particular conflicts, broad parameters that fit most conflicts can be identified. Strategies should address the local roots of hostility; the local capacities for change; and the (net) specific degree of international commitment available to assist change. One can conceive of these as the three dimensions of a triangle, whose area is the "political space"-or effective capacity-for building peace. We test these propositions with an extensive data set of 124 post-World War Two civil wars and find that multilateral, United Nations peace operations make a positive difference. UN peacekeeping is positively correlated with democratization processes after civil war and multilateral enforcement operations are usually successful in ending the violence. Our study provides broad guidelines to design the appropriate peacebuilding strategy, given the mix of hostility, local capacities, and international capacities.
\end{abstract}




\section{Introduction}

The collapse of state institutions in Somalia, a coup in Haiti, and civil wars in Bosnia, Cambodia, El Salvador, Guatemala and other countries have marked the distinctive contours of civil strife in the past decade. The international community's responses to these emergencies has, despite sometimes major efforts, been mixed at best: occasional successes in restoring a legitimate and effective government are matched by striking failures to do so. The United States and the United Nations intervened in Somalia, but their effort appeared to lack direction. In Cambodia the United Nations undertook a multidimensional peace operation - the United Nations Transitional Authority in Cambodia - but the peace it left behind in 1993 was partial at best, suffered a coup in 1997, and now (2000) struggles ahead in a renewed coalition government. In El Salvador, Guatemala, Namibia, Eastern Slavonia (Croatia) and Mozambique peace is firmer. But even there the long run prospects of social integration nonetheless remain problematic. In Bosnia, de facto partition still holds sway in most of the country and current stability is a direct function of NATO (SFOR) peacekeeping. Now the international community has intervened and assumed temporary sovereignty in Kosovo and East Timor and the tasks of assisting the development of viable polities there have barely begun.

One of the most important challenges the international community faces is the question of how to rebuild stable polities in the aftermath of civil war. How can the international community assist former combatants with a will to peace to prevent renewed hostility and to contain the ambitions of those who seek renewed civil war? What role should the international community play in ensuring that failed states do not relapse into chaos as soon as the international peacekeepers leave? The United Nations and various regional organizations, including NATO, have accepted the responsibility to undertake "post-conflict peacebuilding" and commissioned their member states to undertake extensive intrusions into the domestic affairs 
of other legally sovereign states. ${ }^{1}$ What guidelines should be developed to help steer these ambitious mandates?

In current usage in the UN and among the private voluntary organizations, peacebuilding is an attempt, after a peace has been negotiated or imposed, to address the sources of present hostility and build local capacities for conflict resolution. Strengthening state institutions, increasing political participation, engaging in land reform, deepening civil society, finding ways to respect ethnic identities: all are seen as ways to improve the prospects for peaceful governance. ${ }^{2}$ In plural societies, conflicts are inevitable. The aim of peacebuilding is to build the social, economic and political institutions and attitudes that will prevent the inevitable conflicts that every society generates from turning into violent conflicts. ${ }^{3}$ In effect, peacebuilding is also the front line of preventive action.

\section{Strategies of Peacebuilding}

The political strategy of a peacebuilding mandate is the concept of operations embodied in its design. Just as civil wars are usually about failures of legitimate state authority, sustainable civil peace relies on its successful reconstruction. Peacebuilding is about what needs to happen in between. Civil wars arise when individuals, groups and factions discover that a policeman, judge, soldier or politician no longer speaks and acts for them. Rather than "the local cop on the beat," the cop becomes "the Croatian, Serb or Muslim cop." When the disaffected mobilize, acquire the resources needed to risk an armed contest, and judge that they can win, civil war follows. ${ }^{4}$

Although we can imagine purely cooperative solutions to domestic peace, ${ }^{5}$ the confusion, "noise," violence, and changing identification that characterize the onslaught and conduct of civil war do not seem to be promising circumstances for rational cooperation among factions. Instead the establishment of civil peace seems to require addressing directly both the defensive and 
aggressive incentives that motivate faction leaders (and sometimes their followers). Defensive incentives arise in the domestic "security dilemma." Under emerging conditions of anarchy (the collapse of central authority) each group/faction seeks to arm itself in order to be protected; but, as in inter-state anarchy, each defensive armament constitutes a threat to other factions (Posen, 1993). Offensive incentives arise because factions and their leaders will want to impose their ideology or culture, to reap the spoils of state power, to seize the property of rivals, or to exploit public resources for private gain, or all of the above. Establishing peace will thus also require the elimination, management or control of "spoilers" (Stedman, 1997) or war entrepreneurs (DeFigueiredo and Weingast, 1999).

Conquest by one faction can solve the problem (but even in this case political and social reconstruction can be vital for longer-term legitimacy and stability). Peace through agreement can employ the separation of populations and territorial partition to address war-prone incentives (Kaufmann, 1996). Civil wars can be turned into international wars (as in Eritrea-Ethiopia) or stable and relatively secure international or inter-communal balances of power, as in Cyprus or Somaliland-Somalia, for example (Herbst, 1996/97). To each spoiler, his or her separate pile of spoils. But in many civil wars the contest is over who or what "ideology" controls a single polity. Moreover, in some ethnic wars the costs of ethnic "cleansing" will seem too high, or a common basis for over-arching civic citizenship exists or can be created. Combatants in these circumstances still have continuing disputes over material interests, who or what rules, and safety. They have each experienced devastating destruction (though in varying degrees) and both leaders and followers are likely to harbor deep resentment for losses sustained, particularly to family and village members. They also are experiencing the costs of war and may have come to "hurting stalemate," in which no faction sees that it can win and each is experiencing net costs of continuing strife (Zartman, 1985). In these latter circumstances, sustainable peace needs state 
authority as a starting point to overcome security concerns. Hobbes's Leviathan - state sovereignty, or authority - fills that role, restoring "legitimate power."6

The specific motivations that shape the behavior of combatants are thus complex and varied. The classical, Thucydidean and Hobbesian trinity of motives (fear, honor, interest) are present in modern variations --security dilemmas, ethnic identity and/or ideological fervor, and loot-seeking-- and each of them is complicated by potential differences between leaders and followers, and factions and patrons. Thus, the decision to organize or participate in a rebellion and then attempt to achieve a viable peace is not a straight-forward matter and may differ greatly across actors. What each motivated actor shares, however, is a political environment in which success in achieving peace depends on the degree of harm sustained, the resources available for development, and the international assistance to overcome gaps. Low levels of economic development and other deficiencies in local capacities may motivate actors to violence, due to the low opportunity cost of war and the opportunities for private gains from violence (Collier and Hoeffler 1999). Increased hostility due to the experience of war makes reconciliation more difficult. To achieve peace and reconciliation under these circumstances, I.William Zartman (1995) has argued that we need some combination of (1) re-concentrating central power (the powerful must be recognized as legitimate; or the legitimate, made powerful); (2) increasing state legitimacy through participation (elections, power-sharing); and (3) raising and allocating economic resources in support of peace. Given the devastation of civil war; all three generally require (4) external, international assistance or international authority in a transitional period. ${ }^{7}$

It is this last dimension that is the particular focus of this article. What role does external international assistance play in the peace process? How much and of what kind is required? We will argue that the levels of war-related hostility and the pre- and post-war levels of local capacities interact with present international capacities to deliver specific post-conflict outcomes. 
And, for given levels of local capacity and hostility, we will identify the right form of international assistance to maximize the available space for peace.

\section{A Peacebuilding Triangle}

International peacebuilding strategies, concepts of operations, should be "strategic" in the ordinary sense of that term, matching means to ends. Although a peacebuilding strategy must be designed to address a particular conflict, broad parameters that fit most conflicts can be identified. Strategies should address the local sources of hostility; the local capacities for change; and the (net) specific degree of international commitment available to assist change. One can conceive of the three as the three dimensions of a triangle, whose area is the "political space"or effective capacity—for building peace. This metaphor suggests that the dimensions substitute for each other-more of one substitutes for less of another, less extreme hostilities substitute for weak local capacity or minor international commitment.

International commitment (or lack thereof) interacts with local capacities and factional hostility to shape the triangular peacebuilding "space;" for few peacebuilding plans work unless regional neighbors and other significant international actors desist from supporting war and begin supporting peace. ${ }^{8}$ The end of Cold War competition thus was an important precondition for the bloom of peacebuilding operations of the early 1990's. Beyond that minimum, international peacebuilding, from monitoring to enforcement, also makes a difference. We divide international peacebuilding into four types of mandated operations:

Monitoring or Observer Mission is an interim arrangement used in violent conflicts, with the consent of the host government and where there is no formal determination of aggression, aimed at monitoring a truce and assisting the negotiation of a peace through the presence of military and civilian observers. 
Traditional Peacekeeping involves the deployment of military units and civilian officials in order to facilitate the negotiated settlement of a conflict. It is based on the consent of the parties (normally authorized under Chapter VI of the UN Charter). Traditional peacekeeping operations (PKOs) typically establish and police a buffer zone and assist the demobilization and disarmament of military forces.

Multidimensional Peacekeeping is also consent based and is designed to implement a comprehensive negotiated peace agreement. It includes a mix of strategies to build a self-sustaining peace, ranging from those of the traditional PKOs to more multidimensional strategies for capacities-expansion (e.g. economic reconstruction) and institutional transformation (e.g. reform of the police, army, and judicial system, elections, civil society re-building).

Peace Enforcement is a (usually multilateral) military intervention, authorized under Chapter VII of the UN Charter, designed to impose public order by force, if needed, with or without host government consent.

International peacebuilding mandates must take into account the characteristics of the factions. Peacebuilding operates not upon stable states but, instead, on unstable factions. These factions (to simplify) come in two, few or many and in various dimensions of hostility based upon how much damage each has done to the other. The more hostile and numerous the factions, the more difficult the peace process will be and the more international assistance/authority will be needed if peace is to be established.

In less hostile circumstances (with few factions, a hurting stalemate, or less harm done) international monitoring might be sufficient to establish transparent trust and self-enforcing peace. Monitoring helps create transparency among partners lacking trust but having compatible incentives favoring peace. Traditional peacekeeping assistance can also reduce tradeoffs (helping, for example, to fund and certify the cantonment, demobilization and reintegration of 
former combatants). In these circumstances -- with few players, substantially compatible incentives, some reconciliation, less damage - international coordination and assistance can be sufficient to overcome hostility and solve implementation problems. An international peacekeeping presence itself can deter defections from the peace treaty, because of the possible costs of violating international agreements and triggering further international involvement in an otherwise domestic conflict.

In more hostile circumstances, international enforcement can help solve commitment and cooperation problems by directly implementing or raising the costs of defection from peace agreements. International enforcement and long term trusteeship will be required to overcome deep sources of distrust and powerful incentives to defect from agreed provisions of the peace. As in other conflictual-cooperative situations such as prisoner's dilemma and mixed motive games (Axelrod and Keohane, 1985; Oye, 1985), the existence of deeply hostile, or many factions or factions that lack coherent leadership complicate the problem of achieving selfenforcing cooperative peace. Instead, conscious direction and enforcement by an impartial international agent to guarantee the functions of effective sovereignty become necessary and peacebuilding comes to include activities such as conducting a free and fair election, arresting war criminals, and policing and administering a collapsed state.

War-torn countries also vary in economic and social capacity. Some war-torn countries started out with considerable economic development (the former Yugoslavia) and retain levels of social capacity in an educated population. Others began poor and the war impoverished them further (Angola, Sudan, Cambodia). In both cases reconstruction is vital; the more the social and economic devastation, the larger the multidimensional international role must become, whether consent-based multidimensional peacekeeping or non-consent enforcement followed by and including multidimensional peacekeeping. International economic relief and productive jobs are the first signs of peace that can persuade rival factions to truly disarm and take a chance 
on peaceful politics. Institutions need to rebuilt, including a unified army and police force and the even more challenging development of a school system that can assist the reconciliation of future generations. ${ }^{9}$

There thus should be a relation between the depth of hostility, the number and character of the factions and the level of economic development, on the one hand, and the extent of international assistance and effective authority, whether monitoring or enforcement, needed to build peace, on the other. In a world where each dimension is finite we can expect, first, that compromises will be necessary to achieve peacebuilding success; and second, that the international role will be significant in general and successful when it is designed to fit the case.

\section{Theoretical Hypothesis and Research Design}

The rational choice theory of civil war occurrence is relevant to the calculations parties make to support or reject peace after the fighting ends. Simply put, we would observe warrecurrence if the expected utility of war is greater than the expected utility of peace. Such a model underpins recent studies of civil war occurrence and termination, such as Collier and Hoeffler (1998, 2000), Azam (1995), Hirschleifer (1987), and Mason and Fett (1996). These studies assume that the warring parties are rational though not infallible; that war generates private and public gains and losses which are unevenly distributed; that private gains explain why war may be rational for some groups; and that war is collectively suboptimal, hence also collectively irrational. These assumptions allow analysts to make a series of hypotheses regarding the likelihood of war. But the likely results of such a decision-making model would clearly depend heavily on a further set of detailed assumptions. ${ }^{10}$

We do not intend in this paper to model a specific decision-making framework, but rather to explore the correlates of all decision-making with respect to peacebuilding after civil war. We will argue that the probability that peacebuilding will succeed is a function of a 
country's material and institutional capacities, the available international assistance, and the depth of war-related hostility. The relations among them are complicated. The availability and prospect of international assistance and the existence of extensive local capacities, for example, can both raise the gains from victory (spoils of war and rebuilding assistance) and reduce the costs of fighting (as the assistance serves to sustain the fighting). So, too, deep war-related hostilities can have dual effects. We will argue more specifically in net: (a) that the decision to support peacebuilding (PB) is enhanced by both local and international capacities for peace; (b) that net local capacities (NLC) are given by the difference between local capacities (LC) or developmental potential minus war-generated hostility $(\mathrm{H})$; and $(\mathrm{c})$ that international capacities (IC) can substitute for deficiencies in local capacities to compensate for the depth of hostility. Thus, we theorize that the PB process is captured by expression (2): PB = IC * NLC. That relationship is loosely reflected in the shape of a "peacebuilding triangle" (see Figure 1). ${ }^{11}$

\section{Insert Figure 1 about here}

This convenient shape makes it possible to visualize our key hypotheses since the three sets of variables interact competitively ( $\mathrm{H}$ vs. IC and LC) and cooperatively (LC and IC) to produce a space for peace. Specifically, this interactive model posits that: ${ }^{12}$ (a) The larger the international capacities (IC), the higher the probability of PB success, given hostility (H) and local capacities (LC); (b) The greater (deeper) the hostility, the lower the probability of PB success, given LC and IC; and (c) The larger the local capacities, the higher the probability of PB success, given $\mathrm{H}$ and IC.

We will test our interactive model by identifying and measuring proxy variables for Hostility, Local Capacities, and International Capacities and by computing the relative significance of each of these determinants for peacebuilding success. This is the first quantitative analysis of the correlates of successful peacebuilding and of the contribution of UN peace operations to peacebuilding outcomes. ${ }^{13}$ Our analysis maps the strategic environment 
within which actors make their decisions to support peace or war and we explain how best to use UN peace operations to prevent civil wars from recurring.

\section{The Data}

To test our hypothesis, we constructed a new cross-sectional data set of all civil wars since 1944. Our statistical analysis focuses on civil wars that ended by 1997 , so that we can measure peacebuilding outcomes at least two years after the end of the war. However, we also include a few cases of ongoing wars if a peace operation has been initiated since our interest is in the effectiveness of such operations in ending war and restoring peace. ${ }^{14}$ Refer to Appendix A for further discussion of case selection.

We define a civil war as an armed conflict which meets all the following conditions: the conflict has (a) caused more than one thousand deaths overall and in at least a single year; (b) it has challenged the sovereignty of an internationally recognized state; (c) it occurred within the recognized boundary of that state; (d) it involved the state as a principal combatant; (e) it included rebels with the ability to mount organized armed opposition to the state; and (f) the parties were concerned with the prospect of living together in the same political unit after the end of the war. This definition allows us to combine wars from several data sets.

\section{Our Explanatory Variables}

To test our hypothesis, we selected proxy variables that are theoretically consistent with the interactive model presented above and which forge links with the earlier civil war literature. Thus, we proxy the level of hostility by the number of deaths and displacements, the type of conflict, the number of hostile factions, the level of ethnic division, and the outcomes of the war (see Appendix $\mathrm{C}$ for summary statistics and a list of sources for our key variables). We proxy local capacities by a set of socio-economic measures of development, such as real per capita GDP, energy consumption, and natural resource-dependence; and international capacities by the duration, strength, and mandate of peace operations, if any were used and by the amount of 
economic assistance available to the country at war. We control for the government's capacity to defend itself by the size of the government army and we also control for systemic constraints, such as the Cold War or the decade during which the war started.

Our main concern is with how international capacities - UN peace operations in particular-influence the probability of peacebuilding success. We therefore collected data on all UN operations and classified them into four types described above: ${ }^{15}$ Monitoring or Observer Mission; Traditional Peacekeeping; Multidimensional Peacekeeping; and Peace

\section{Enforcement.}

\section{Our Dependent Variable}

Our main dependent variable is PBS2_-peacebuilding success or failure two years after the end of the war. We also measure PB outcomes five and ten years after the war (Appendix B explains our coding method). PBS2 is a binary variable, coded 1 if we observe a PB success and 0 otherwise. We use a lenient (PBS2L) and a strict (PBS2S3) version of this variable (and also use different thresholds for the strict version) to test the robustness of our findings. The lenient version of PB implies an end to the war and to residual lower-level violence and uncontested sovereignty. Thus, it represents a minimum (or negative) measure of peace, focused on the absence of violence. There are 71 (57.26\%) lenient PB failures and 53 successes (42.74\%).

The stricter version of PB also requires a minimum standard of democratization. ${ }^{16} \mathrm{We}$ prefer it because it reflects a higher-order of peace while requiring only a minimum standard of political openness. There are $81(65.32 \%)$ strict PB failures and $43(34.68 \%)$ successes. Table 1 lists all civil war events since 1944 and presents two-year PB outcomes for all these events. ${ }^{17}$ 


\section{Ten Policy-Relevant Hypotheses}

To achieve easily interpretable results with straight-forward policy implications, we interpret our interactive model of PB as a set of associations between PB outcomes and our proxies for Hostility, Local Capacities, and International Capacities. We use these proxies to make ten policy-relevant hypotheses below:

Hypothesis 1: The probability of peacebuilding (PB) success should be lower in identity wars (i.e. ethnic and religious wars). Hostility is easily channeled across ethnic lines and several other scholars have identified the ease with which ethnic passions can be mobilized into support for ethnic war (Lake and Rothschild 1998; Weingast and DeFiguereido 1999). Further, the ease of ethnic identification makes it harder to reconcile differences among combatants after civil war (Kaufman 1996).

Hypothesis 2: The probability of PB success should be lower the greater the human costs of the war (deaths and displacements). ${ }^{18}$ Human costs also proxy the level of wargenerated hostility. We measure total deaths -including civilian casualties — and displacements (refugees and internally displaced persons) that resulted from the war. The greater the costs the lower a society's social and human capital and the lower its ability to rebound after civil war. Further, the greater these costs, the deeper the social-psychological barriers to building peace.

Hypothesis 3: Partly in contradiction to the above, we expect the probability of PB success to be higher the longer the war. ${ }^{19}$ This may seem counter-intuitive. One may reasonably argue that longer wars should increase hostility as they also create more casualties (other things being equal). However, war duration also makes the parties tired of fighting and resolves any pre-war uncertainty about the probability of military victory or the parties' relative resolve. ${ }^{20}$ Hence, we would expect that longer wars offer a chance for the parties to learn by reflecting on the benefits of peace and by controlling war-related hostility. 
Hypothesis 4: The probability of PB success should be lower the larger the number of factions. More factions imply a larger pool of potentially divergent preferences, which makes it harder to negotiate a cooperative equilibrium (Keohane and Axelrod 1986). As discussed in previous sections, many factions tend to increase the level of hostility. We also hypothesize, however, that the relationship between the number of factions and PB outcomes is nonmonotonic. While the initial impact of increasing numbers of factions is negative, at very large numbers of factions, the probability of PB success may rise, as cross-cutting coalitions emerge. Intermediate levels of factions should make peace bargaining harder because it is easier to forge cross-cutting coalitions among larger groups of factions than among a few polarized groups. ${ }^{21}$

Hypothesis 5: The probability of PB success decreases with increases in ethnic heterogeneity. Although ethnic groups need not be hostile toward one other, we can assume that each group will have different preferences over the terms of a settlement or other distributive issues. Thus, coordination over a mutually acceptable peacebuilding equilibrium should be harder the greater is ethnic heterogeneity. Collier and Hoeffler (2000), Collier, Hoeffler and Soderbom (1999), and Elbadawi and Sambanis (2000) have shown that ethnic polarization significantly increases the risk of civil war, but high levels of both ethnic homogeneity and ethnic heterogeneity reduce that risk. Bates (1999) has found a similar relationship with reference to Africa. Thus, we would also expect a similar effect in peacebuilding processes for the same reasons: ethnically polarized societies should be less able to cooperate in a peace process than ethnically homogeneous or very heterogeneous societies.

Hypothesis 6: The probability of $\mathrm{PB}$ success should be higher the higher the per capita income and the higher the country's overall economic development level. More developed economies with lower levels of poverty should be both better able to re-build after war and less susceptible to war-recurrence due to economic grievance. Poverty has been shown by many studies to motivate large-scale violent conflict (e.g. Collier and Hoeffler 2000). Thus, the greater 
this economic measure of local capacities, the easier it will be to compensate for war-generated hostility and the higher the probability of PB success.

Hypothesis 7: A related hypothesis is that the risk of new war-hence the probability of peacebuilding failure-should be higher in highly resource-dependent countries. Examples of this relationship are the civil wars in Angola, Sierra Leone, and Liberia, where the rebels have financed their activities by diamond looting and the wars themselves could have been lootoriented (Collier and Hoeffler 2000). Natural resource-dependence further implies an undiversified economy, more vulnerable to commodity price shocks and less able to develop manufactures and services that develop human capital and facilitate economic growth.

Hypothesis 8: The probability of peacebuilding success should be higher if the war ends in a peace treaty. Treaties are indicators of post-war levels of hostility since, at the moment of signing, they typically represent the parties' will to end the violent phase of their conflict. Further, treaties enable international involvement, in the form of lending, foreign aid programs, transfers of goods and services, and the deployment of UN peace operations. Thus, treaties should be significant for peacebuilding, while controlling for these related variables.

Hypothesis 9: The probability of PB success should be higher if UN peace operations are employed. UN operations signal international interest in ending the conflict and offer needed assistance to the parties. They also imply the transfer of much needed international assistance and technical expertise which compensates for war-related hostility and low-levels of domestic capacities, as outlined in our interactive model.

Hypothesis 10: The probability of PB success should be higher the stronger the UN peace operation and the more extensive its mandate. While it is important for the UN and other multilateral actors to become involved in a peace process, the right mandate should be used. Thus, we would expect monitoring, traditional and multidimensional peacekeeping operations 
(PKOs) to have a different effect than peace enforcement operations. All such operations, however, should increase the probability of PB success.

\section{Empirical Findings and Interpretation}

We tested these hypotheses by estimating logistic models of peacebuilding outcomes

with robust standard errors and clustered same-country observations. ${ }^{22}$ Our models include at least two proxies for each of our three core sets of variables - hostility (H), local capacities (LC), and international capacities (IC). ${ }^{23}$ We controlled for systemic factors by adding a dummy and interaction variables for the Cold War (COLDWAR). ${ }^{24}$ Since we believe that the Cold War was more relevant in determining violence levels than democratization levels and since there has been a clear democratization trend over time in most countries, we used Cold War as a control variable for the lenient (violence-focused) PB model and a variable denoting the Decade during which the war started (DECADE) as a control variable for the strict (democratization-focused) PB model. Table 2 presents the results of our model, estimated two and five years after the end of the civil war both for strict and lenient PB. We also used two democratization thresholds to code the strict PB version to test the model's robustness.

[Insert Table 2 About Here]

\section{Strict Peacebuilding Success (PBS2S3)}

Our theoretical model is strongly supported by the empirical evidence. We find (Models A-D) that international and local capacity and hostility variables are all significant determinants of higher-order peacebuilding as theorized. Local capacities are the least robust, perhaps due to the fact that they reflect pre-war levels of capacity and one would expect wars in different countries to have a differential effect on those countries' post-war development capacity. ${ }^{25} \mathrm{We}$ find that war-related Hostility (LOGCOST) substantially reduces the likelihood of PB success and that, the greater the international capacities the larger the probability of PB success. Notice 
that, by signing a treaty and inviting a UN peace operation, the parties are several times more likely to achieve peace (see the odds ratios for those two variables). We also find that higher levels of Net current transfers (TRNSFCAP, which includes unilateral transfers, food aid, etc.) substantially increase the probability of PB success, as do higher levels of Economic development (DEVELOP), whereas that probability is reduced significantly if the country is heavily Resource-dependent (EXP), since that would suggest a low level of economic development and an undiversified economy. Wars with an ethnic or religious overtone are less likely to be resolved, as are wars with large numbers of factions (more on the non-monotonic effect of factions later). Finally, we find that these relationships become stronger as we become stricter on our definition of peace (compare Models A and B to C and D). For higher-order peace, local capacities are more significant and the duration of the war is also important, with longer wars supporting the PB process (Model D). Our control variable suggests that higherorder PB has become less likely over time (since the coefficient of Decade is negative).

\section{Lenient Peacebuilding Success (PBS2L)}

Our model is slightly less accurate with respect to lenient PB. Whereas Models A-D correctly predict an average of $85 \%$ of the cases in our data set, models E-F correctly predict $80 \%$ of cases. Local capacity variables are now not significantly correlated with PB and only resource-dependence continues to have a significant and negative effect among LC variables (one-tailed test). Treaties are also less significant (the odds ratio drops by about half), though hostility variables (deaths, displacements, war type, and number of factions) become much more significant (the odds ratios double in some cases). While international capacities are still important, it is Net current transfers (TRNSFCAP) that are more significant and peace operations become marginally significant. War duration (WARDUR) is not significant in ending violence, seemingly in contradiction to the war-weariness hypothesis (though this effect is also driven by a few outliers --see below). The Cold War is highly significant in the very short-run, 
increasing the likelihood of lenient peace more than fourfold, which suggests that systemic constraints were important in preventing war/violence.

Our results in both the strict and lenient model are broadly consistent in the 2- and 5-year periods, which strengthens our confidence in our model. ${ }^{26}$ We anticipate some outliers in this model, given the idiosyncratic nature of many wars, so our classification success of $80-85 \%$ is satisfactory. ${ }^{27}$ Perhaps more important is the fact that our model wrongly predicts a PB success for an actual PB failure only $7 \%$ of the time (i.e. the model errs on the side of caution) and robustness and diagnostic tests convinced us that our models are well-specified and robust. ${ }^{28}$

Our main interest is to explain how higher-order PB can be achieved, especially as a result of international peacebuilding. ${ }^{29}$ We have therefore focused closely on Model A (strict PB for the short-term), conducting sensitivity analysis by making small specification changes to that model in Table 3 (where we report odds ratios and z-values). We do not focus on classification success in Table 3, but rather test the impact of specification changes on the coefficients and standard errors of key variables. Tables 2 and 3 provide us with a test of our ten hypotheses.

\section{[Insert Table 3 About Here]}

\section{Policy Hypotheses Tests}

In what follows, we mainly discuss the short-term (2 year) strict PB model and we discuss the lenient model's results only if they are significantly different from the strict model. Hypothesis 1: ACCEPT

Identity wars (WARTYPE $=1$ ) are highly significant and negatively correlated with peacebuilding success for both the lenient and strict PB models. This is an extremely robust variable across all specifications of the model, but its odds ratio is quite small. In Model A, Table 2, and Models A1-A8, Table 3, the odds ratio for war type never rises above .2, which therefore suggests that while the influence of this variable is consistently negative, its overall impact on the probability of PB success is relatively small. Thus, while Identity wars have 
successful PB processes with lower probability than non-identity wars, that difference is not very large. For lenient PB (Models E-F), Identity wars' odds ratio is slightly larger, but it is still small relative to other variables. This small increase in the odds ratio suggests that war type is more relevant to ending the violence than to the process of political reform during peacebuilding.

\section{Hypothesis 2: ACCEPT}

Human misery created by the war is consistently and negatively associated with PB success, both lenient and strict. This result holds with respect to both the absolute level of Human cost (LOGOST, in all models of Table 2) and for Per capita human cost (COSTCAP, Model A2, Table 3). The odds ratio of Human cost is considerable and it is larger for the lenient than for the strict version of PB. Thus, we find consistent evidence that hostility variables are more significant for ending the violence than for democratization once the violence has ended. ${ }^{30}$ Hypothesis 3: ACCEPT (w/ reservations)

War duration (WARDUR) is positively correlated to PB success in both lenient and strict models (Table 2), but it is only significant for strict PB. (However, if we dropped the two largest outliers, WARDUR would be highly significant at the 0.001 level.) ${ }^{31}$ We find War duration not to be robust to different specifications of the model (see Table 3) due to war duration's correlation with hostility and local capacity variables. ${ }^{32}$ If we dropped the Human cost variable, War duration would lose all significance. However, War duration is more significant for strict PB with higher democracy thresholds (Models C and D, Table 2), which suggests that "war-weariness" may influence the political reform process rather than the decision to stop fighting. Finally, if we cluster our observations by broad geographical region rather than by country (since regional influences are important in peace processes), we find that War duration would be significant at the 0.05 level in the core specification of model A of Table 2 (results available from the authors). 


\section{Hypothesis 4: ACCEPT}

The Number of factions (FACTNUM) is significant and negatively associated with PB success, both strict and lenient (Table 2). The quadratic term (FACTNUM2) is positively associated with PB success, as theorized, but it is only significant for strict PB, for the lower democracy threshold. Thus, we can accept the theorized non-monotonic relationship between Number of factions and PB only for the strict version of PB and only for low levels of democratization. Beyond that, the Number of factions has a strictly negative impact on $\mathrm{PB} .{ }^{33}$

\section{Hypothesis 5: REJECT}

Ethnic heterogeneity $(\mathrm{EH})$ is not significantly correlated with PB success (Model A1,

Table 3). The mean value of Ethnic heterogeneity is only slightly lower (less than 4 percentage points) in PB successes than in failures (both strict and lenient). More importantly, the coefficient of Ethnic heterogeneity is positive, which contradicts our original hypothesis (though the coefficient changes sign if we drop other variables from the model). We also used an index of Ethnolinguistic fractionalization (ELF), which is widely used in the literature (e.g. Mauro 1995) and which measures the probability that any two randomly selected people from different ethnic groups speak the same language. This variable was also not significant (results available from the authors). We also entered Ethnic heterogeneity as a quadratic, following some of the literature on civil wars (Elbadawi and Sambanis 2000), but again we found no significance. Further, dropping Identity wars and Number of factions from the model did not improve the significance of the Ethnic heterogeneity variable.

This is an important result, because several authors have identified Ethnolinguistic fractionalization as a key variable in the economic literature on the onset and duration of civil wars (Collier and Hoeffler 2000; Collier, Hoeffler and Soderbom 1999) and in the literature on economic growth (Easterly and Levine 1997; Mauro 1995; Alesina, Easterly, and Baquir 1997). Our results could be due to a selection effect, especially if ethnic diversity is a significant 
determinant of the initiation of civil wars. However, Collier and Hoeffler (2000) find that linguistic and religious diversity actually reduce the risk of civil wars, which does not suggest that our results are due to selection problems. Thus, we are inclined to interpret the difference between the importance of ethnicity for war duration as opposed to peacebuilding as evidence that while wars fought over ethnicity or religion are difficult to settle the mere presence of ethnic diversity does not mean that populations will continue to fight.

\section{Hypothesis 6: ACCEPT_STRICT PB; REJECT_LENIENT PB}

The overall level of Economic development (DEVELOP) as proxied by per capita consumption of electricity (see note 22 for additional measurement information) is positively correlated with PB success in both lenient and strict models (Table 2). It is weakly significant for strict PB with a one-tailed test (Model A), but not for lenient PB (Models E, F). Thus, we have to reject our hypothesis for the lenient model: positive local capacities seem consistently irrelevant for lenient PB, i.e. for ending the violence. However, local capacities facilitate higherorder peacebuilding (compare the coefficients and significance levels of Economic development in models $\mathrm{C}$ and $\mathrm{D}$, where we have used a higher threshold of democratization for coding a PB success). Finally, clustering our observations by geographical region leads us to find Economic development significant at the 0.05 level in the core specification of model A of Table 2 (results available from the authors).

\section{Hypothesis 7: ACCEPT}

Natural resource-dependence, proxied by the share of primary exports in GDP (EXP), is significantly and negatively associated with PB success, both lenient and strict (one-tailed test). This finding effectively links our paper with the economic literature on the causes of civil wars, which has identified Natural resource-dependence as one of the main culprits in loot-seeking civil wars (Collier and Hoeffler 2000). Easily looted resources provide incentives for new wars, 
which would expectedly reduce the probability of PB success. We find our results on Natural resource-dependence relatively robust to different specifications of the strict PB model.

\section{Hypothesis 8: ACCEPT}

The hypothesis that treaties are positively correlated with PB success is resoundingly accepted both for the lenient and strict PB models (Table 2). Importantly, other war outcomes are not significant determinants of peacebuilding. For example, Military victory (MILOUT in Model A3, Table 3) is completely non-significant and this finding does not change if we discriminate between government and rebel victory (the latter results available from the authors). Informal truces are not significantly associated with strict PB and they have a negative sign.

\section{Hypothesis 9: ACCEPT-STRICT; REJECT-LENIENT}

UN presence (UN2INT) without specifying the operation's mandate was positively and significantly correlated with strict PB (Model A4, Table 3). However, it is not significant for lenient $\mathrm{PB} .{ }^{34}$ Note that there is a high positive correlation between $U N$ presence and Treaty (38\%) since treaties are necessary for many UN peacekeeping operations. Thus, if we dropped Treaty from the lenient model, UN presence would become significant at the $5 \%$ level. But so far it seems that treaties do the heavy lifting and we must acknowledge that simple UN involvement is not enough to strengthen a war-to-peace transition. The operation's mandate is critical.

\section{Hypothesis 10: ACCEPT}

UN peace operations classified according to their mandate are highly significant determinants of peacebuilding processes, but this relationship is quite complex. Notice that the UN operation type (UN2CINT) is positively and significantly correlated with strict and lenient PB (Table 2), but that the coefficient of UN operation type drops by about half in the lenient model (Models E \& F). What does this suggest about the significance of the type of operation? It is not possible to identify the impact of specific operation types using the UN operation type 
variable, so we unpacked it into its various components and focused specifically on mediation efforts (good offices, envoys, fact-finding) in Model A5, enforcement in model A6, traditional peacekeeping in Model A7, and multidimensional peacekeeping in Model A8 of Table 3.

Model A5 reveals that UN mediation (UN2INT2) alone is an insufficient strategy. While not significant, the coefficient of UN mediation is negative. These operations offer additional transparency but lack of commitment of resources (military and economic) to influence the incentives of the parties to resolve a violent conflict. Model A6 replaces the previous UN variables with a dummy variable for UN enforcement (UNTYPE5). We find that this variable is positively associated with strict PB success, but it is not significant (the same is true for the fiveyear version of the PB variable). Thus, the international community cannot count on enforcement alone to build higher-order peace. ${ }^{35}$ These enforcement operations thus do appear to have a positive role in ending violent conflict.

Models A7 and A8 reveal perhaps the most interesting results with respect to UN peace operations. We find that Traditional peacekeeping (UNTYPE3) is not at all significant in enhancing the prospects for peacebuilding success and that it even has a negative sign in the lenient version of the model (results available from the authors). In these latter situations one observes the syndrome of "peacekeeping without a peace to keep." By contrast, Multidimensional PKOs (UNTYPE4) -i.e. missions with extensive civilian functions, including economic reconstruction, institutional reform, elections, etc.-are extremely significant and positively associated with strict $\mathrm{PB}$, a participatory peace. (Notice the high odds ratio of Multidimensional PKOs in Model A8, Table 3.)

In sum, we found that UN enforcement can help end a war but that it has little effect on institutionalizing participatory peace (our strict PB). By contrast, Multidimensional PKOs seem both to contribute to a reduction in violence (lenient PB; results available from authors) and as crucially to higher-order peace, the strict PB which involves institutional and political reform, 
holding of elections, democratization.

\section{Does the UN Pick its Fights? Two Technical Though Substantive Issues}

Our analysis so far has suggested that the UN can play an important role in peacebuilding. However, our results suggest that not all types of UN operations are right for all types of jobs. We were further concerned that some of our findings might be due to selection effects or influenced by the potential endogeneity of UN peace operations. We therefore briefly examined both these problems and found that neither alters our findings.

First, let us summarize the concern with the potential endogeneity of UN operations. Given the high degree of correlation between the deployment, mandate, and strength of UN operations and variables that determine PB outcomes, we were concerned that the UN's decision to intervene might have been determined by some of these other variables. It may have been the case, for example, that the UN picked the easy fights. Conversely, the UN might have decided heroically to intervene only in the severest of conditions. To test that possibility, we estimated two-stage models of peacebuilding, instrumenting for the UN presence. We do not present the statistical results in detail, since they do not alter our findings. First, we identified a number of good instruments for UN presence, such as a dummy variable for Europe (EURO), Real GDP per capita (GDP), Third party partial intervention (INTERVEN), NOUNCINT (non-UN peace operation), and Military outcome (MILOUT). We then estimated a 2-stage least squares (2SLS) linear probability model, a 2-stage probit model, and a bivariate probit model with selection and found no evidence of endogeneity of UN presence. A Smith-Blundell test of exogeneity for the core strict PB model A, using the instruments identified above, yields a Chi-squared(1) test = .4118 with a P-value $=.521$, which does not allow us to reject the null hypothesis of exogeneity. ${ }^{36}$ That test leads us to reject exogeneity only if we use TREATY as an instrument and not as an exogenous variable in the structural equation, which would be incorrect given the 
significant relationship between TREATY and strict PB. Further, even if we were to assume that $U N$ presence is in fact endogenous, a linear probability model of strict PB (specified as above and using TREATY as an instrument) yields a highly significant coefficient estimate for $U N$ presence $(.497)$ with a robust standard error equal to $.152 .{ }^{37}$ Given that most of the models estimated reveal no evidence of endogeneity, we can rely on our previous inferences.

A second possible complication arises from the difference in the standard error of $U N$ presence in the strict vs. lenient PB model, raising concerns over possible selection effects. That discrepancy may have been due to a different effect of UN peace operations on the probability of ending the violence as opposed to the level of democratization following the end of the war. Given that such a democratization process is observed only after the war ends in our data set, there is a legitimate concern over potentially important selection effects. We therefore estimated a Heckman selection model in Table 4, to test if such selection effects have a significant impact on the efficiency of our previous parameter estimates.

\section{[Insert Table 4 About Here]}

We specified two variations of this model to test the significance for democratization of peacekeeping as opposed to enforcement operations. Model 1 distinguishes between traditional and multidimensional PKOs, while Model 2 combines the two. The estimates in Model 1 show that Multidimensional PKOs are highly significant and positively correlated with the level of democratization that is observed after the war ends and that they also help end the violence (see the results in the selection equation). By contrast, UN enforcement operations are significant in ending the violence, but are non-significant and negatively associated with democratization. In model 2, the variable denoting all types of PKOs combined is not strongly significant, especially for ending the violence, but also for democracy. The results with respect to enforcement are comparable to Model 1. We control for war duration, which is positive and significant, and for 
the pre-war 5-year democracy average (GURRLAG5) in our models. We find that a pre-war tradition of democratic institutions is the surest way to achieve democratization after a civil war.

Model 1 yields a Wald test of independent equations of $X^{2}(1)=0.92\left(\operatorname{Pr}>X^{2}=0.3368\right)$ and model 2 yields a $X^{2}(1)=1.16\left(\operatorname{Pr}>X^{2}=0.2816\right)$. These tests do not allow us to reject the null hypothesis of independent equations, which means that the estimates presented earlier in Tables 2 and 3 are more efficient and that we can rely on them for our inferences. While the Heckman selection models did not cause us to change our estimation methods, they amplified our earlier arguments regarding the differential effects of PKOs and enforcement operations and they helped us disentangle the impact of different types of UN operations on democracy.

We can now argue with greater confidence that, the higher up we move in the spectrum of peace, the less we need muscular third-party assistance and the more we need specialized peace operations with a developed civilian component. Furthermore, enhancing local capacities is more important for higher-order peacebuilding than for lower-order peacebuilding, while reducing the depth of hostility is more important for lower-order peacebuilding.

\section{Index Models of Peacebuilding Success}

Having completed our tests of our policy-relevant hypotheses, we now return to our core model by aggregating our proxies for Hostility (H), Local Capacities (LC), and International Capacities (IC) in three indices and estimating our models of strict and lenient peacebuilding using the indices as regressors. We ran many regressions with several combinations of those indices to ensure that our results were not driven by the construction of the index. Our results are summarized in Table 5 for a single combination of indices.

\section{[Insert Table 5 About Here]}

We regressed the indices on the 2- and 5-year versions of lenient and strict $\mathrm{PB}$. We find all three indices highly significant in all models and their coefficient signs are those predicted by our PB triangle theory. Increasing International Capacities and Local Capacities compensate for 
increasing levels of Hostility. However, in varying the composition of the indices, we found more significant combinations for the Hostility and International Capacities indices than for the Local Capacities index, especially with reference to the lenient PB model. Thus, the results of the index models are in line with the previous discussion of individual proxies.

\section{COMPARATIVE STATICS AND POLICY ANALYSIS}

Armed with these findings, we can now use our core model to analyze the interactions between key explanatory variables and the probability of PB success using conditional effects plots (see Figure 2). The four panels of Figure 2 graph the estimated probability of strict PB success for the inter-quartile difference in a key variable (i.e. the difference between the bottom and top $25^{\text {th }}$ percentile of that variable), while allowing another key regressor to vary throughout its range. Non-varying regressors are set at their median levels.

\section{[Insert Figures 2 \& 3 About Here]}

Panel 2.1 maps the probability of PB success for the inter-quartile range of Human cost, which proxies Hostility at all levels of Economic Development, which proxies Local Capacities. We see clearly that PB success is not only much more likely if hostility levels are shallow (contrast the circle-studded to the triangle-studded lines), but also that the rate of increase in the probability of success rises faster as local capacities also rise. Wealth does appear to make a reconciled peace easier, especially if the two sides have avoided the worst forms of mutual violence.

Panel 2.2 maps the probability of PB success for variable Economic Development with and without a UN peace operation. The probability of PB success is remarkably higher if a PKO is used, meaning the parties have also signed a peace agreement. At high levels of local capacity, the probability of PB success when there is a peace treaty and a PKO is near unity. The difference is great also at low levels of economic development, where a treaty and PKO 
substitute for the lack of local capacities (contrast the circle-studded and triangle-studded lines at very low levels of electricity consumption per capita). The differential impact of a UN PKO and a peace treaty is maximized at middle-levels of local capacities.

Panel 2.3 maps the probability of PB success for variable Number of factions and for the inter-quartile range of Local Capacities (low LC implies low development levels and high natural resource-dependence). The Number of factions has a clearly non-monotonic (U-shaped) effect on the probability of peacebuilding. The lowest probability of success occurs at around 57 factions. The probability is highest when the Number of factions is small, but overall, we find that there is not much interaction between the number of factions and local capacity levels, since the inter-quartile difference in the probability of PB success is quite small.

Panel 2.4 maps the probability of PB success for variable levels of Human Cost for Identity wars and non-Identity wars. We see a huge difference in the probability of PB success at low levels of Human Cost and that, in general, non-Identity wars are most likely to result in a PB success. Identity wars are four times harder to resolve at extremely low levels of Human Cost, but at extremely high levels of Human Cost, both types of war are equally unlikely to result in a PB success. This evidence suggests that the impact of war type is overwhelmed by the Human Cost of the war; Cambodia, an ideological war with a non-ethnic massacre of more than a million, and Rwanda, an identity war with a genocide of more than 500,000, come out as similarly challenging cases in terms of the difficulty of achieving PB success. This plot emphasizes as well how important early intervention can be before the parties have done extensive killings and especially in a non-identity war. That is when the probability of PB success is greatest.

Using our Model A of Table 2, we could compute the probability of strict PB success for conflicts that have just ended. ${ }^{38}$ A perhaps more valuable product of our analysis is that it allows us to assess the contribution International capacities make to the resolution and prevention of 
future civil war. Using our model, we can identify broad guidelines for peacebuilding strategies after civil war, given different levels of Local capacities and Hostility. We focused on the role of UN operations and can now draw some broad guidelines for UN involvement using Figure 3.

For simplicity, we can imagine that peacebuilding processes can be divided into "difficult" and "easy" cases. A difficult case would be one in which all the variables with a negative-sign coefficient in our model would have high values (setting them at the top $25 \%$ of their range) whereas all the positive-sign variables would have low values (setting them at the bottom $25 \%$ of their range). We focus on such differences in the levels of hostility and local capacities and identify the impact of UN peacekeeping and a peace treaty in difficult vs. easy cases. $^{39}$

Panels 3.1 and 3.2 represent two such difficult cases, whereas panels 3.3 and 3.4 represent two easy cases. Panel 3.1 maps the probability of PB success for a bad case with variable hostility levels and contrasts a scenario where there is no UN operation or peace treaty to one where there is both a treaty and a PKO. The results are striking: a difficult case without a treaty or PKO even at the lowest level of hostility has a very low probability of PB success, several times lower than if a PKO had been deployed and a treaty signed. Peacekeeping does make a positive difference and early intervention pays. But at very high levels of hostility, after massive civilian slaughter, the two probabilities converge to low levels, though there is still a slightly greater chance of success with a PKO and treaty. These results are almost the mirror opposite of those for an easy case (Panel 3.3). Here, the probability of success is quite high at low levels of Hostility (deaths and displacements), regardless of whether or not a PKO is present or a treaty signed. The major impact of the treaty and PKO comes at high levels of hostility, where they are crucial in maintaining the probability of PB success at high levels. Without a treaty/PKO, the probability of success drops substantially from an initial value of between $60 \%$ $70 \%$ to under $5 \%$ at extreme values of hostility. This appears, for example, to map the situation 
in Bosnia today, a more developed country that has suffered many casualties and that is held together in peace by NATO, the UN, and a plethora of other international organizations.

Panel 3.2 maps the probability of PB success for a difficult case at all levels of Economic development both with and without a $\mathrm{PKO} /$ treaty (a bad case here refers to high levels of hostility). Here we see that a treaty/PKO are even more important for PB success since the slope of the curve with PKO gets much steeper much sooner than the slope of the curve without a PKO and the resulting probability of success without a treaty/PKO is minimal even at extremely high levels of economic development. By contrast, panel 3.4 maps the probability of PB success for variable local capacities and an easy case (i.e. low hostility). The impact of a PKO and a treaty in this case is highest at very low levels of development, whereas neither a treaty nor a strong international presence seems necessary for PB success at very high levels of development. Developed countries that have experienced minor civil violence can put themselves back together. The UN is most needed elsewhere, in the less developed countries that have suffered extensive violence.

\section{CONCLUSION}

Our analysis has identified the critical determinants of peacebuilding processes. We have found that higher-order peacebuilding is more likely after non-identity wars, after long and not very costly wars, in countries with relatively higher development levels and where UN peace operations and substantial financial assistance are available. Lower-order peacebuilding — an end to the violence-is more dependent on muscular third-party intervention and on low hostility levels rather than on the breadth of local capacities.

Peacemaking aimed at facilitating a peace treaty is potentially life saving, since we found peace treaties highly correlated with an end to the violence. Moreover, strategically designed peacekeeping and peace enforcement does make a difference. International capacities can foster 
peace by substituting for limited local capacities and alleviating deep hostility factors in order to improve the prospects that peace will be successfully restored, but only if the peace operations are appropriately designed. Purely enforcement operations can end the violence; but they cannot promote higher-order peace. By contrast, consent-based peacekeeping operations with civilian functions (multidimensional PKOs), which usually do not have the mandate to end the violence if parties do not cooperate, are not usually successful in ending violence. But, with a peace treaty and the cooperation of the parties, PKOs can assist higher-order peacebuilding -- the institutional and political reform that helps secure longer term peace. Truly intractable conflicts, such as the ones in Bosnia, Kosovo, and East Timor, will thus probably require both enforcement and peacebuilding operations, coordinated and in the right order. 


\section{APPENDIX A: CODING GUIDELINES FOR CASE-SELECTION}

This data set includes 124 events of civil war. Included are all wars since 1944. The analysis in the paper includes only wars that terminated before 1997 and wars that were ongoing as of December 1999 but had at least one significant settlement or truce or third-party peace operation since 1997. This allows us to evaluate peacebuilding outcomes at least two years after either the end of the war or the beginning of a peace operation (if the war is ongoing). The beginning of a peace operation signals the parties' desire to terminate the war and restore peace at a point in time, hence our decision to include in our analysis of peacebuilding the few cases of ongoing war in which peace operations are deployed.

Our definition of civil war (see text) is nearly identical to the definitions in Singer and Small $(1982 ; 1994)$ and Licklider $(1993 ; 1995)$. Our coding of wars also reflects the 1,000 annual battle deaths standard in coding a war event. In addition, we code a war as having ended when a peace treaty is signed or one side has achieved victory. We relaxed the 1,000 annual death thresholds for coding civil violence as a war in a few cases because we felt that the overall amount of violence and the nature of that violence (i.e. a state fighting against organized rebel groups enjoying popular support) and most of our other criteria were satisfied. In fact, the 1,000 annual death criterion seems rather arbitrary and we could not corroborate that all cases in the Singer and Small (1994) data-set actually caused more than 1,000 deaths annually during all years of the war. Moreover, the Singer and Small (1994) codebook does not refer to an annual death threshold as a coding condition (rather this is referred to in their 1982 book, $\underline{\text { Resort to }}$ $\underline{\text { Arms) }}$ and no annual death data are made available by the Correlates of War Project.

Our definition of a civil war allows us to combine observations from several data-sets, such as Singer and Small (1994); Uppsala University project on civil wars/Wallensteen and Sollenberg (various years); The State Failure Project (1997); Licklider (1995; 1993); Mason and Fett (1996); Regan (1996); Walter (1997); SIPRI yearbooks (1987-1998); secondary texts, 
including case-studies and official reports, such as: Doyle, Orr, and Johnstone (1997) on Cambodia and El Salvador; Rotberg (1998) on Burma; Deng (1999) on the Sudan; Stuart-Fox (1998) on Laos; Human Rights Watch reports on Sierra Leone, Democratic Republic of the Congo, Uganda, Kosovo, Bosnia, and Algeria; State Department reports on Bangladesh, Laos, Burma, Chad, Djibouti, Egypt, Cambodia, Guinea-Bissau, Peru, and the Philippines. Other sources include the CIA World Factbook (various years) and Brogan (1992).

The most important difference between our coding of wars and the coding of other authors, refers to the periodization of wars. We have tried to apply consistently the following criterion in coding separate war events: we code a separate war event if the parties sign a peace treaty, or if the fighting breaks for a prolonged period (up to two years). By applying this coding criterion, we have in some cases collapsed two or more observations in other data sets or, conversely, we have divided a single observation in two or more war events. For more details on our application of this coding rule, see the section "Country-Specific Comments" in the online documents (http://www.worldbank.org/research/conflict/papers/peacebuilding).

Our reason for adopting this coding rule was that our research question focuses on peacebuilding efforts. Thus, we needed to evaluate the success or failure of every significant attempt at peace and all the above criteria used to apply our coding rule would suggest that the war has subsided, presenting an opportunity for peacebuilding. If a peace operation was implemented and the war resumed, that is clear evidence of peacebuilding failure and we therefore needed to include these cases of ongoing war in our analysis. Other rules of thumb for coding separate war events were the following:

- If a different war started while a previous war was ongoing in the same country, we coded separate war events (e.g. the Tigrean and Eritrean wars in Ethiopia). 
- If the parties and issues to a war changed dramatically, we coded a separate event (e.g. the Afghan war before and after Taliban). We collapsed two or more war events in other datasets in one if the parties and issues were the same.

- If less than 2 years intervened between the first and second event we collapsed observations in other data-sets into a single war event.

- If the war ended officially through an agreement but fighting did not subside, we considered the war as ongoing and coded a single event. Mason and Fett $(1996$, fn. 8) do the same.

\section{APPENDIX B: CODING GUIDELINES FOR THE DEPENDENT VARIABLES}

Our dependent variables are Lenient peacebuilding (PB) and Strict PB. There are three intermediate variables used in the construction of the dependent variables: War End (WAREND), No Residual Violence (NOVIOL), and Democracy (GURR). Each intermediate variable has two versions, one for the two-year period after the end of the war and another for the five-year period. Each of these versions in represented by a suffix after the computer abbreviation of the variable name. We explain the coding process below in four steps: First, did the war end (was there no war recurrence)? We coded the variable War End (WAREND) two and five years after the war. The variable abbreviations are WAREND2 and WAREND5, respectively. These are coded as 1 if the war ended and 0 otherwise. We used the same sources and rules as for coding war events.

Second, did low-level violence end after the war? We coded the variable No Residual Violence (NOVIOL) two and five years after the war. The variable abbreviations are NOVIOL2 and NOVIOL5, respectively. These are coded as 1 if there was no residual violence and 0 otherwise. NOVIOL2 and NOVIOL5 are coded 0 if war recurred (i.e. if WAREND2 or WAREND5 = 0); if other data sets (State-Failure Project 1995; Regan 1996; Wallensteen and Sollenberg 1997) code 
an ongoing low-level or intermediate armed conflict; or if a politicide or genocide occurred after the end of the war (our sources for this were Gurr and Harff 1988; 1994; and Licklider 1995). Third, what was the level of democratization after the end of the war? We coded the variable Democracy (GURR2 and GURR5) measuring democracy from the Polity98 (June 1999) data, as the sum of: [Democracy $+(10$ - Autocracy $)]$, two and five years after the end of the war. This variable ranges from 0 (extreme autocracy) to 20 (maximum democracy).

Fourth, the dependent variables can now be coded as follows:

Lenient PB success two years after the war (PBS2L) and Lenient PB success five years after the war (PBS5L) are coded 1 if there was a success and 0 otherwise. We coded PBS2L $=1$ (success), if WAREND2 $=1 \&$ NOVIOL2 $=1$, and if state sovereignty is not divided (i.e. state authority can be exercised in the entire territory of the state). We coded PBS2L $=0$ otherwise. We coded the five-year version of the dependent variable (PBS5L) in a similar fashion but used the two-year period in our analysis because many important wars had not ended for more than 5 years up to the time of writing.

Strict PB success two years after the war (PBS2S) and five years after the war (PBS5S) are coded as follows: PBS2S $=1$ if PBS2L $=1 \&$ GURR2 $>$ (a democratization threshold - see below). PBS2S $=0$, otherwise. We coded the five-year version of this variable analogously. The strict version of $\mathrm{PB}$ thus involves more than an end to the violence and is our preferred measure of PB success or failure. We created two sub-categories of strict PB, using a low democracy threshold (GURR = 3), which we prefer because it places fewer demands on the country shortly after the end of the war and a higher threshold $($ GURR $=6)$ to code variables PBS2S3 and PBS2S6, respectively. We coded the five-year versions of the variable (PBS5S3, PBS5S6) analogously. For ongoing conflicts, we used democracy data for 1998 because we do not have more recent data from the Polity98 project. Finally, we coded a score of -77 (“interregnum") in the Polity98 data set as a PB failure. 
APPENDIX C: Summary Statistics and Sources for Our Explanatory Variables

\begin{tabular}{|c|c|c|c|c|c|c|}
\hline Variable & Obs & Mean & S.D. & Min & $\operatorname{Max}$ & Source \\
\hline $\begin{array}{l}\text { Ethnic/Religious War? } \\
\text { (WARTYPE) }\end{array}$ & 124 & 0.64 & 0.48 & 0 & 1 & $\begin{array}{l}\text { State Failure Project (1995); Licklider (1995) } \\
\text { Various secondary sources (see bibliography) }\end{array}$ \\
\hline $\begin{array}{l}\text { Log of dead/displaced } \\
\text { (LOGDEAD) }\end{array}$ & 123 & 11.91 & 2.41 & 6.91 & 15.7 & $\begin{array}{l}\text { Singer and Small (1994); Licklider (1995), } \\
\text { Brogan (1992), HRW reports; various sources }\end{array}$ \\
\hline $\begin{array}{l}\text { Dead/displaced per capita } \\
\text { (COSTCAP) }\end{array}$ & 123 & 0.11 & 0.21 & 1.16 & 1.66 & $\begin{array}{l}\text { as above; population data from US Bureau of } \\
\text { the Census and World Bank WDI database }\end{array}$ \\
\hline $\begin{array}{l}\text { War duration (months) } \\
\text { (WARDUR) }\end{array}$ & 124 & 78.73 & 92.96 & 1 & 600 & $\begin{array}{l}\text { Singer and Small (1994); Wallensteen and } \\
\text { Sollenberg (1997); Licklider (1995) }\end{array}$ \\
\hline $\begin{array}{l}\text { Number of factions } \\
\text { (FACTNUM) }\end{array}$ & 124 & 3.32 & 1.52 & 2 & 11 & $\begin{array}{l}\text { Brown (1996); various secondary sources (see } \\
\text { bibliography) }\end{array}$ \\
\hline $\begin{array}{l}\text { Ethnic heterogeneity } \\
\qquad(\mathrm{EH})\end{array}$ & 124 & 56.91 & 34.04 & 0 & 144 & $\begin{array}{l}\text { Tatu Vanhanen - Journal of Peace Research } \\
\text { Ethnolinguistic Fractionalization Index (ELF) } \\
\text { source is Mauro (1995) }\end{array}$ \\
\hline $\begin{array}{l}\text { Net transfers per capita } \\
\text { (TRNSFCAP) }\end{array}$ & 123 & 58.43 & 171.1 & -112 & 1272.5 & $\begin{array}{l}\text { IMF Financial Statistics, 1949-1998 } \\
\text { World Bank, World Development Indicators } \\
1999\end{array}$ \\
\hline $\begin{array}{l}\text { Type of UN operation } \\
\text { (UN2CINT) }\end{array}$ & 124 & 0.83 & 1.24 & 0 & 4 & $\begin{array}{l}\text { Blue Helmets (1996); and web-site of UN } \\
\text { Department of Peacekeeping Operations }\end{array}$ \\
\hline $\begin{array}{l}\text { UN Mediation } \\
\text { (UN2CINT2) }\end{array}$ & 124 & 0.07 & 0.26 & 0 & 1 & $\begin{array}{l}\text { Blue Helmets (1996); and web-site of UN } \\
\text { Department of Peacekeeping Operations }\end{array}$ \\
\hline $\begin{array}{l}\text { Traditional PKO } \\
\text { (UNTYPE3) }\end{array}$ & 124 & 0.06 & 0.25 & 0 & 1 & $\begin{array}{l}\text { Blue Helmets (1996); and web-site of UN } \\
\text { Department of Peacekeeping Operations }\end{array}$ \\
\hline $\begin{array}{l}\text { Multidimensional PKO } \\
\text { (UNTYPE4) }\end{array}$ & 124 & 0.06 & 0.23 & 0 & 1 & $\begin{array}{l}\text { Blue Helmets (1996); and web-site of UN } \\
\text { Department of Peacekeeping Operations }\end{array}$ \\
\hline $\begin{array}{l}\text { UN enforcement } \\
\text { (UNTYPE5) }\end{array}$ & 124 & 0.03 & 0.18 & 0 & 1 & $\begin{array}{l}\text { Blue Helmets (1996); and web-site of UN } \\
\text { Department of Peacekeeping Operations }\end{array}$ \\
\hline $\begin{array}{l}\text { Was a treaty signed? } \\
\quad(\text { TREATY) }\end{array}$ & 124 & 0.28 & 0.45 & 0 & 1 & $\begin{array}{l}\text { Walter (1997); Licklider (1995); Wallensteen } \\
\text { and Sollenberg (1997); secondary sources }\end{array}$ \\
\hline $\begin{array}{l}\text { Military outcome to war? } \\
\text { (MILOUT) }\end{array}$ & 124 & 0.60 & 0.49 & 0 & 1 & $\begin{array}{l}\text { Walter (1997); Licklider (1995); Wallensteen } \\
\text { and Sollenberg (1997); secondary sources }\end{array}$ \\
\hline $\begin{array}{l}\text { Pre-war democracy index } \\
\text { (GURRLAG5) }\end{array}$ & 120 & 6.017 & 5.68 & 0 & 20 & $\begin{array}{l}\text { Jaggers and Gurr (Polity98 data base) } \\
\text { ftp://isere.colorado.edu/pub/datasets/polity } 98\end{array}$ \\
\hline
\end{tabular}




\begin{tabular}{c|ccccccc}
$\begin{array}{c}\text { Electricity consumption per } \\
\text { capita (DEVELOP) }\end{array}$ & 124 & 540.8 & 851.1 & 10 & 5387 & $\begin{array}{l}\text { World Bank, WDI database. (Also source for } \\
\text { GDP data used to impute missing values) }\end{array}$ \\
$\begin{array}{c}\text { Primary exports as percent } \\
\text { of GDP (EXP) }\end{array}$ & 124 & 0.12 & 0.08 & 0.01 & 0.51 & $\begin{array}{l}\text { World Bank, WDI database. } \\
\text { http://www.worldbank.org/data }\end{array}$ \\
$\begin{array}{c}\text { Decade dummy for war } \\
\text { start (DECADE) }\end{array}$ & 124 & 3.45 & 1.43 & 1 & 6 & $\begin{array}{l}\text { Based on war-start data from Singer and Small } \\
(1994) ; \text { Licklider (1995); etc (see Appendix A) }\end{array}$ \\
$\begin{array}{c}\text { Cold War dummy } \\
\text { (CODLWAR) }\end{array}$ & 124 & 0.78 & 0.41 & 0 & 1 & $\begin{array}{l}\text { Coded } 1 \text { for war-starts before } 1989 \text { and } 0 \text { for } \\
\text { war starts after } 1989\end{array}$ \\
\hline
\end{tabular}




\section{REFERENCES}

Alvarez, M. and Glascow. 2000. “Two-Stage Estimation of Non-Recursive Choice Models,” Political Analysis 8 (December): 147-165.

and L. Butterfield. 2000. "The Resurgence of Nativism in California? The Case of

Proposition 187 and Illegal Immigration,” Social Science Quarterly (forthcoming).

Alesina, Easterly, and Baquir. 1999. "Public Goods and Ethnic Divisions.” Policy Research

Working Paper 2108. Washington, DC: World Bank.

Allen, Woody. 1976. Without Feathers. New York: Warner Books.).

Annan, Kofi. 1998. The Causes of Conflict and the Promotion of Durable and Sustainable

Peace in Africa: Report of the Secretary-General. New York: United Nations.

Arendt, Hannah. 1961. "What is Authority" in Between Past and Future. New York: Viking. Pp.

$91-141$.

Axelrod, Robert and Robert Keohane. 1985. “Achieving Cooperation Under Anarchy.” World Politics 38 (1): 226-54.

Azam, Jean Paul. 1995. "How to Pay for Peace." Public Choice 83 (1/2): 173-184.

Bates, Robert H. 1999. "Ethnicity, Capital Formation, and Conflict." CID Working Paper no. 27. Cambridge, MA: Harvard University.

Blainey, Geoffrey. 1973. The Causes of War. New York: Free Press.

Bollen, K. A., D. K. Guilkey, and T. A. Mroz. 1995. "Binary Outcomes and Endogenous

Explanatory Variables: Tests and Solutions with an Application to the Demand for Contraceptive Use in Tunisia.” Demography 32 (February): 111-131.

Boulding, Kenneth. 1964. "Toward a Theory of Peace," in Roger Fisher, ed. International

Conflict and Behavioral Science. New York: Basic Books. Pp. 70-87.

Boutros-Ghali, Boutros. 1992. An Agenda for Peace. New York: United Nations.

Brogan, Patrick. 1992. The Fighting Never Stopped: A Comprehensive Guide to World Conflict 
Since 1945. New York: Random House.

Brown, Michael, ed. 1996. International Dimensions of Internal Conflict. Cambridge, MA: MIT Press.

Chopra, Jarat. 1999. Peace Maintenance. London: Routledge.

CIA World Factbook. http://www.odci.gov/cia/publications/factbook/index.html. (August 14, 2000).

Collins, Cindy and Thomas Weiss. 1997. "An Overview and Assessment of 1989-1996 Peace

Operations Publications." Occasional Paper, No. 28 Thomas J. Watson Institute. Providence: Watson Institute.

Collier, Paul and Anke Hoeffler. 2000. “Greed and Grievance in Civil War.” World Bank Policy Research Paper 2355 (May).

Collier, Paul. 1999. "On the Economic Consequences of Civil War." Oxford Economic Papers, 51(January): 168-83.

Collier, Paul, Anke Hoeffler, and Mans Soderbom. 1999. “On the Duration of Civil War." Unpublished paper (http://www.worldbank.org/research/conflict/papers/duration.htm) (August 14, 2000).

Cousens, Elizabeth, Chetan Kumar, and Karin Wermester, eds. 2000. Peacebuilding as Politics: Cultivating Peace in Fragile Societies. Boulder, CO: Lynne Rienner Publishers.

David, Steven. 1997. "Internal War: Causes and Cures." World Politics 49 (July): 552-76.

DeFigueiredo, Rui and Barry Weingast. 1999. "The Rationality of Fear: Political Opportunism and Ethnic Conflict." In Barbara Walter and Jack Snyder, eds. Civil Wars, Insecurity, and Intervention. New York: Columbia University Press.

DeNardo, James. 1985. Power in Numbers: The Political Strategy of Protest and Rebellion. Princeton: Princeton University Press. 
Deng, Francis M. 1999. War of Visions: Conflict of Identities in the Sudan. Washington, DC: Brookings.

Deutsch, Karl and J. David Singer. 1964. "Multipolar Systems and International Stability." World Politics 16(April): 390-406.

Diehl, Paul F., Jennifer Reifschneider, and Paul R. Hensel. 1996. "United Nations Intervention and Recurring Conflict.” International Organization 50(Autumn): 683-700.

Doyle, Michael, Ian Johnstone and Robert Orr, eds. 1997. Keeping the Peace: Multidimensional UN Operations in Cambodia and El Salvador. Cambridge: Cambridge University Press.

Durch, William, ed. 1993. The Evolution of UN Peacekeeping. NY: St. Martin's Press. ed. 1996. UN Peacekeeping, American Politics, and the Uncivil Wars of the 1990's. NY: St. Martin's Press.

Easterly, William and Ross Levine. 1997. “Africa’s Growth Tragedy: A Retrospective, 196089." Policy Research Working Paper 1503. Washington, DC: World Bank.

Elbadawi, Ibrahim and Nicholas Sambanis. 2000. “How Much War Will We See? Estimating the Incidence and Amount of Civil War in 161 Countries.” Working Paper (August) World Bank DECRG.

Esty, Daniel C., Jack Goldstone, Ted Robert Gurr, Barbara Harff, Pamela T. Surko, Alan N. Unger, and Robert Chen. 1998. "The State Failure Project: Early Warning Research for US Foreign Policy Planning." In John L. Davies and Ted Robert Gurr, eds. Preventive Measures: Building Risk Assessment and Crisis Early Warning Systems. Boulder, CO and Totowa, NJ: Rowman and Littlefield.

Evans, Gareth. 1993. Cooperating for Peace. London: Allen and Unwin.

Eckstein, Harry. 1964. Internal War: Problems and Approaches Glencoe: Free Press. Fearon, James. 1995. "Rationalist Explanations for War.” International Organization 49(Summer): 379-414. 
Fearon, James and David Laitin. 1996. "Explaining Interethnic Cooperation.” American Political Science Review 90(December): 715-35.

Franck, Thomas. 1998. "A Holistic Approach to Peace-building." In Olara Otunnu and Michael Doyle, eds. Peacemaking and Peacekeeping for the New Century. Rowman and Littlefield. Freedom House. 1999. "Annual Survey of Freedom Country Scores: 1972-73 to 1998-99." http://www.freedomhouse.org. (January 4, 2000.)

Goulding, Marrack. 1993. "The Evolution of United Nations Peacekeeping," International Affairs 69(3): 451-64.

Gurr, Ted Robert. 1994. "Peoples Against States: Ethnopolitical Conflict and the Changing World System.” International Studies Quarterly 38(September): 347-77.

Gurr, Ted. 1993. Minorities at Risk. Washington, DC: USIP.

Gurr, Ted Robert and Barbara Harff. 1997. “Internal Wars and Failures of Governance, 195496" http://www.bsos.umd.edu/cidcm/stfail/sfcodebk.htm (March 21, 2000). 1994. Ethnic Conflict and World Politics. Boulder, CO: Westview Press.

Haas, Ernst B. The United Nations and Collective Management of International Conflict. New York: UNITAR, 1986.

, Lyle Butterworth, and Joseph Nye. 1972. Conflict Management by International Organization. Morristown, NJ: General Learning Press.

Hampson, Fen. 1996. Nurturing Peace. Washington, DC: USIP.

Hegre, Håvard, Tanja Ellingsen, Nils Petter Gleditsch \& Scott Gates. 1999. "Towards a Democratic Civil Peace? Opportunity, Grievance, and Civil War, 1816-1992." Paper presented at the World Bank Conference on The Economics of Political and Criminal Violence (February 16-22). http://www.worldbank.org/research/conflict/papers/peace.htm (August 14, 2000). 
Herbst, Jeffrey. 1996/97. "Responding to State Failure in Africa." International Security 21(Winter): 120-144.

Heston, Alan and Robert Summers. 1991. "The Penn World Table (Mark 5): An Expanded Set of International Comparisons, 1950-1988." Quarterly Journal of Economics (May): 327--368. Data-file (Version 5.6, January 1995) http://cansim.epas.utoronto.ca:5680/pwt/pwt.html

Hirschleifer, J. 1987. "Conflict and Settlement." In Eatwell, J., Milgate M., and P. Newman, eds. New Palgrave, A Dictionary of Economics. London: Macmillan Press.

Human Rights Watch. World Report (various years). New York/Washington DC: HRW.

Iatrides, John O. 1993. "The Doomed Revolution: Communist Insurgency in Postwar Greece." In Roy Licklider, ed. Stopping the Killing. New York: NYU Press.

Jaggers, Keith and Ted R. Gurr. 1999. Polity 98. ftp://isere.colorado.edu/pub/datasets/polity98. Kacowicz, Arie. 1994. Peaceful Territorial Change. Columbia: University of South Carolina Press.

Kaufmann, Chaim. 1996. "Possible and Impossible Solutions to Ethnic Conflict.” International Security 20 (Spring): 136-175.

Lake, David and Donald Rothchild. 1996. "Containing Fear: The Origins and Management of Ethnic Conflict." International Security 21 (Fall): 41-75.

Licklider, Roy. 1993. Stopping the Killing: How Civil Wars End. NY: NYU Press. . 1995. "The Consequences of Negotiated Settlements in Civil Wars, 1945-1993." American Political Science Review 89 (September): 681-90.

McDowall, David. 1996. A Modern History of the Kurds. New York: St. Martin's Press.

Maddala, G.S. 1983. Limited Dependent and Qualitative Variables in Econometrics. Cambridge: Cambridge University Press.

Mason, D. and P. Fett. 1996. "How Civil Wars End: A Rational Choice Approach.” Journal of Conflict Resolution 40 (December): 546-68. 
Mauro, Paolo. 1995. "Corruption and Growth.” Quarterly Journal of Economics CX (August): 681-711.

Olson, Mancur. 1993. "Dictatorship, Democracy, and Development." American Political Science Review 87 (September): 567-76.

Oye, Kenneth. 1985. "Explaining Cooperation Under Anarchy.” World Politics 38 (1): 1-24.

Paris, Roland. 1997. "Peacebuilding and the Limits of Liberal Internationalism." International Security 22 (Fall): 54-89.

Posen, Barry. 1993. 'The Security Dilemma in Ethnic Conflict.” In Michael Brown, ed. Ethnic Conflict and International Security. Princeton: Princeton University Press. Pp. 103-124.

Ratner, Steven. 1995. The New UN Peacekeeping. NY: St. Martin's.

Regan, P. 1996. “Conditions for Successful Third Party Interventions.” Journal of Conflict Resolution 40(1): 336-59.

.2000. "Third Party Interventions and the Duration of Intrastate Conflicts.” Working

Paper, Workshop on the Economics and Politics of Violence, Princeton University March 1819, 2000.

Rivers, D. and Q. Vuong. 1988. “Limited Information Estimators and Exogeneity tests for Simultaneous Probit Models." Journal of Econometrics 39(January): 347-66.

Rotberg, Robert I., ed. 1998. Burma: Prospects for a Democratic Future. Wash. DC Brookings. Sambanis, Nicholas. 2001. "Civil War: Do Ethnic and Non-Ethnic Wars Have the Same Causes?" Journal of Conflict Resolution (forthcoming in 2001).

Selten, Reinhard. 1973. "A Simple Model of Imperfect Competition: Where 4 are Few and 6 are Many." International Journal of Game Theory 2(3).

Singer, J. David and Melvin Small. 1994. Correlates of War Project: International and Civil War Data, 1816-1992 [Computer file (April)] (Study \#9905). Ann Arbor, MI: Inter-University Consortium for Political and Social Research [distributor]. 
SIPRI. SIPRI Yearbook (various years). http://editors.sipri.se/pubs/yearb.html (March 21, 2000).

Smith, Richard J. and Richard W. Blundell. 1986. "An Exogeneity Test for a Simultaneous Equation Tobit Model with an Application to Labor Supply." Econometrica 54(4): 679686.

Stata Corporation. 1999. Stata Reference Manual: Release 6. College Station, TX: Stata Corp.

Stedman, Stephen. 1997. "Spoiler Problems in Peace Processes.” International Security 22

(Fall): 5-53.

Stuart-Fox, Martin. 1998. A History of Laos. Cambridge: Cambridge University Press.

Tomz, Michael, Jason Wittenberg, and Gary King. 1999. "Clarify: Software for Interpreting and Presenting Statistical Results." (June 1) Version 1.2.1. http://gking.harvard.edu/stats.shtml (January 4, 2000).

UN Department for Development Support and Management Services and UN Industrial Development Organization. 1995. Post-Conflict Reconstruction Strategies, an International Colloquium at Stadtschlaining, 23-24 June, 1995. (Vienna: UN Office in Vienna).

UNCHR. (various years). The State of the World's Refugees. Geneva: UNCHR.

United Nations. 1996. Blue Helmets. New York: United Nations.

Vanhanen, Tatu. 1999. "Domestic Ethnic Conflict and Ethnic Nepotism: A Comparative Analysis." Journal of Peace Research. 36(1): 55-73.

Walter, Barbara. 1997. "The Critical Barrier to Civil War Settlement." International Organization 51 (Summer): 335-64.

Waltz, Kenneth. 1964. "The Stability of a Bipolar World." Daedalus_XCIII (Summer): 881-909. World Bank. World Tables of Economic and Social Indicators, 1950-1992. World Bank International Economics Department WDI database. http://www.worldbank.org/data (August 14, 2000). 
Zartman, I. William. 1985. Ripe for Resolution: Conflict and Intervention in Africa. Oxford: Oxford University Press.

1995. "Putting Things Back Together.” In Zartman, ed. Collapsed States: The

Disintegration and Restoration of Legitimate Authority. Lynne Rienner. Pp. 267-273. 
Figure 1: The Peacebuilding Triangle

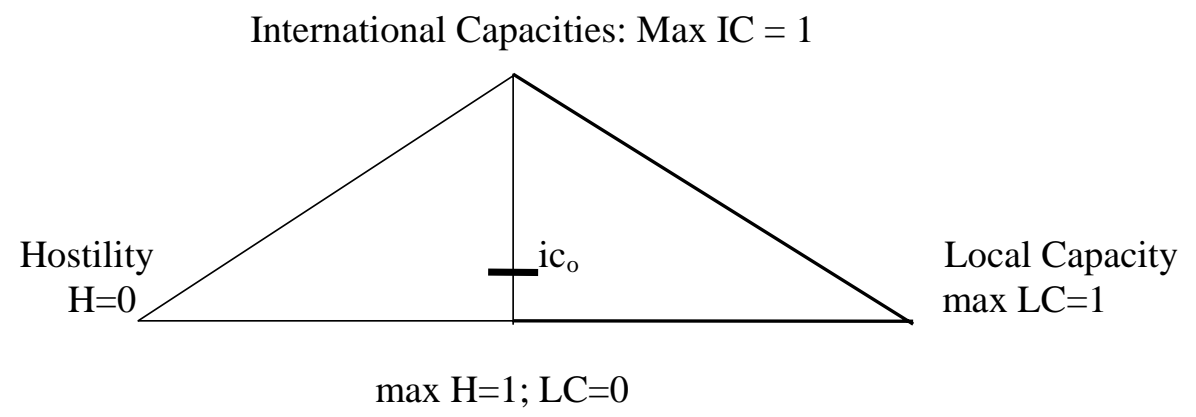


Table 1 - Cases of Internal War and Peacebuilding Outcomes since 1944.

\begin{tabular}{|c|c|c|c|c|c|c|c|c|c|}
\hline Country & Start & End & LenientP & Strict PB & Country & Start & End & LenientPI & \\
\hline Afghanistan & 78 & 92 & Failure & Failure & Iraa/Kurds & 61 & 75 & Failure & Failure \\
\hline Afghanistan & 93 & & Failure & Failure & Iraa/Kurds & 88 & 94 & Failure & Failure \\
\hline $\begin{array}{l}\text { Algeria } \\
\text { la }\end{array}$ & 62 & 63 & Success & Failure & Iraa/Shiites & 91 & 94 & Failure & Failure \\
\hline Algeria & 92 & 97 & Failure & Failure & Israel/Palestine & 47 & 97 & Success & Success \\
\hline Angola & 75 & 91 & Failure & Failure & Jordan & 71 & 71 & Success & Failure \\
\hline & 92 & & Failure & Failure & Kenva & 91 & 93 & Failure & Failure \\
\hline roentina & 55 & 55 & Success & Success & Korea & 50 & 53 & Success & Failure \\
\hline zerbaiian & 88 & 96 & Failure & Failure & Laos & 60 & 75 & & Failure \\
\hline angladesh & 73 & 94 & Success & Success & Lebanon & 58 & 58 & Success & Success \\
\hline & 52 & 52 & & & Lebanon & 75 & 78 & & \\
\hline 3urma & 48 & 51 & Failure & Failure & Lebanon & 82 & 92 & Failure & Failure \\
\hline & 68 & 82 & Failure & Failure & Liberia & 89 & 92 & Failure & Failure \\
\hline 3urma & 83 & 95 & Failure & Failure & Liberia & 93 & 96 & Failure & Failure \\
\hline & 65 & 69 & Failure & Failure & Malav & 48 & 59 & Success & Success \\
\hline 3urundi & 72 & 73 & Success & Failure & Mali & 90 & 95 & cess & Success \\
\hline & 88 & 88 & & & & 92 & 94 & & \\
\hline ndi & 91 & & & & lova & 92 & 94 & & ailure \\
\hline dia & 70 & 75 & lure & & N.Sahara & 75 & 89 & & \\
\hline odia & 79 & 91 & cess & cess & mbiaue & 79 & 92 & cess & ccess \\
\hline Africa & 95 & 97 & & & & 65 & 89 & & \\
\hline had & 65 & 79 & & & gua & 78 & 79 & & lure \\
\hline & 80 & 94 & & & & & 89 & & \\
\hline a/Taiwan & 47 & 47 & & & & 67 & 70 & & ure \\
\hline Tibt & 50 & 51 & & & & 80 & 84 & & \\
\hline & 67 & 68 & & ure & ern & 68 & 94 & ess & ceess \\
\hline bia & 48 & 62 & & & $\mathrm{n} / \mathrm{Ba}$ & 71 & 71 & & cess \\
\hline & 78 & & & & & 73 & 77 & & lure \\
\hline & 92 & 96 & & & N.G & 88 & 91 & & ure \\
\hline /Zaire & 60 & 65 & & & & 47 & 47 & ess & cess \\
\hline /Kisanga & 67 & 67 & & & & 80 & 96 & & ure \\
\hline & 75 & 79 & & & & & & & ess \\
\hline & 96 & 97 & & & & 72 & 96 & & ure \\
\hline & 48 & 48 & & & & & & & ure \\
\hline & 5 & 59 & & & & & & & ess \\
\hline & 6 & 64 & & & Chechnv & 94 & & & ure \\
\hline & 74 & 74 & & & & 63 & & & ure \\
\hline & 91 & 95 & & & & 90 & & & ess \\
\hline & 65 & 65 & & & Leone & 91 & 96 & & \\
\hline & 74 & 92 & & & & 88 & 91 & & \\
\hline & 74 & 91 & & & & 92 & & & lure \\
\hline & 77 & 8 & & & & 76 & 9 & & cess \\
\hline & 74 & 91 & & & & 71 & 71 & & \\
\hline & 91 & 93 & & & & 83 & & & \\
\hline & 92 & 94 & & & & & 89 & & \\
\hline & 44 & 49 & & & & & 72 & & \\
\hline & 5 & 54 & & & & & & & \\
\hline & & 72 & & & & & 94 & & ure \\
\hline & 74 & 94 & & & & & 85 & & ess \\
\hline & 91 & 94 & & & & & & & ure \\
\hline & 9 & 96 & & & & & 66 & & ess \\
\hline & & 4 & & & & & & & \\
\hline & & 65 & & & & & & & \\
\hline & & & & & m. $R e$ & & & & ure \\
\hline & 84 & 94 & & & & & & & ess \\
\hline & & 5( & & & & & & & \\
\hline & 53 & 53 & & & & 62 & & & \\
\hline & & 60 & & & & & & & \\
\hline & 75 & 82 & & & & 9 & & & Failure \\
\hline & 86 & 86 & & & & & & & Failure \\
\hline & 78 & 79 & & & & 95 & & & success \\
\hline & 81 & 82 & & & & 72 & 80 & Failure & Failure \\
\hline $\mathrm{raa} /$ Shammar & & 59 & Failure & Failure & Zimbabwe & 84 & 84 & Success & Success \\
\hline
\end{tabular}


Table 2 - Logistic Models of PB Success 2 \& 5 Years After the End of the War ${ }^{1}$

\begin{tabular}{|c|c|c|c|c|c|c|}
\hline $\begin{array}{l}\text { Independent } \\
\text { Variables }\end{array}$ & $\begin{array}{c}\text { Model A } \\
\text { Strict PB } \\
\text { 2-year } \\
\text { period } \\
\text { Low Dem. }\end{array}$ & $\begin{array}{c}\text { Model B } \\
\text { Strict PB } \\
\text { 5-year } \\
\text { period } \\
\text { Low Dem. }\end{array}$ & $\begin{array}{c}\text { Model C } \\
\text { Strict PB } \\
\text { 2-year period } \\
\text { Moderate } \\
\text { Dem }\end{array}$ & $\begin{array}{c}\text { Model D } \\
\text { Strict PB } \\
\text { 5-year period } \\
\text { Moderate } \\
\text { Dem }\end{array}$ & $\begin{array}{l}\text { Model E } \\
\text { Lenient } \\
\text { PB } \\
\text { 2-year } \\
\text { period }\end{array}$ & $\begin{array}{c}\text { Model F } \\
\text { Lenient } \\
\text { PB } \\
\text { 5-year } \\
\text { period }\end{array}$ \\
\hline CONSTANT & $\begin{array}{c}10.31 * * \\
(2.42) \\
\end{array}$ & $\begin{array}{c}9.62 * * \\
(2.46) \\
\end{array}$ & $\begin{array}{c}7.24 * * \\
(1.91) \\
\end{array}$ & $\begin{array}{c}.65 * * \\
(2.27) \\
\end{array}$ & $\begin{array}{c}5.40 * * \\
(1.72) \\
\end{array}$ & $\begin{array}{c}5.48 * * \\
(1.81) \\
\end{array}$ \\
\hline $\begin{array}{c}\text { WARTYPE } \\
\text { (Identity-based war? } \\
\text { i.e. ethnic/religious) }\end{array}$ & $\begin{array}{c}-2.08 * * \\
(.661) \\
.124 \\
\end{array}$ & $\begin{array}{c}-2.19 * * \\
(.704) \\
.111 \\
\end{array}$ & $\begin{array}{c}-1.94 * * \\
(.609) \\
.143 \\
\end{array}$ & $\begin{array}{c}-2.14 * * \\
(.706) \\
.116 \\
\end{array}$ & $\begin{array}{c}-1.65 * * \\
(.471) \\
.191 \\
\end{array}$ & $\begin{array}{c}-1.77 * * \\
(.48) \\
.169 \\
\end{array}$ \\
\hline $\begin{array}{c}\text { LOGCOST } \\
\text { (Natural log of deaths \& } \\
\text { displacements ) }\end{array}$ & $\begin{array}{c}-.534 * * \\
(.147) \\
.585\end{array}$ & $\begin{array}{c}-.437 * * \\
(.149) \\
.645\end{array}$ & $\begin{array}{c}-.465 * * \\
(.146) \\
.627\end{array}$ & $\begin{array}{c}-.478 * * \\
(.167) \\
.619\end{array}$ & $\begin{array}{c}-.337 * * \\
(.122) \\
.713\end{array}$ & $\begin{array}{c}-.263 * \\
(.129) \\
.768\end{array}$ \\
\hline $\begin{array}{l}\text { WARDUR } \\
\text { (Duration of the war } \\
\text { in months) }\end{array}$ & $\begin{array}{l}.009^{\#} \\
(.005) \\
1.009 \\
\end{array}$ & $\begin{array}{l}.009^{\#} \\
(.005) \\
1.009 \\
\end{array}$ & $\begin{array}{c}.012 * \\
(.0056) \\
1.01 \\
\end{array}$ & $\begin{array}{c}.014^{*} \\
(.006) \\
1.01 \\
\end{array}$ & $\begin{array}{c}.0017 \\
(.003) \\
1.00 \\
\end{array}$ & $\begin{array}{c}.0027 \\
(.003) \\
1.00 \\
\end{array}$ \\
\hline $\begin{array}{c}\text { FACTNUM } \\
\text { (Number of major } \\
\text { factions) }\end{array}$ & $\begin{array}{c}-1.76 * * \\
(.685) \\
.171 \\
\end{array}$ & $\begin{array}{c}-1.88 * * \\
(.673) \\
.151 \\
\end{array}$ & $\begin{array}{c}-1.18 \\
(.649) \\
.304 \\
\end{array}$ & $\begin{array}{c}-1.36 \\
(.739) \\
.254 \\
\end{array}$ & $\begin{array}{c}-.982 \\
(.576) \\
.374 \\
\end{array}$ & $\begin{array}{c}-1.10 * \\
(.577) \\
.331 \\
\end{array}$ \\
\hline $\begin{array}{c}\text { FACTNUM2 } \\
\text { (square of } \\
\text { number of factions) }\end{array}$ & $\begin{array}{l}.114 * * \\
(.056) \\
1.121 \\
\end{array}$ & $\begin{array}{c}.122^{*} \\
(.055) \\
1.13 \\
\end{array}$ & $\begin{array}{c}.0709 \\
(.0579) \\
1.07 \\
\end{array}$ & $\begin{array}{c}.077 \\
(.067) \\
1.08 \\
\end{array}$ & $\begin{array}{c}.048 \\
(.053) \\
1.049 \\
\end{array}$ & $\begin{array}{c}.058 \\
(.054) \\
1.06 \\
\end{array}$ \\
\hline $\begin{array}{c}\text { TRNSFCAP } \\
\text { (Net current account } \\
\text { transfers p.c., current US\$) }\end{array}$ & $\begin{array}{c}.0038 * \\
(.0015) \\
1.003 \\
\end{array}$ & $\begin{array}{c}.0038 * \\
(.0015) \\
1.003\end{array}$ & $\begin{array}{c}.0029 * \\
(.0012) \\
1.00\end{array}$ & $\begin{array}{c}.0028 * \\
(.0014) \\
1.00\end{array}$ & $\begin{array}{c}.003 \\
(.002) \\
1.003\end{array}$ & $\begin{array}{l}.004 * \\
(.002) \\
1.004\end{array}$ \\
\hline $\begin{array}{c}\text { UN2CINT } \\
\text { (Type of UN operation, } \\
\text { by mandate type) }\end{array}$ & $\begin{array}{l}.706 * * \\
(.271) \\
2.027 \\
\end{array}$ & $\begin{array}{c}.684 * \\
(.282) \\
1.98 \\
\end{array}$ & $\begin{array}{l}.694 * * \\
(.261) \\
2.00 \\
\end{array}$ & $\begin{array}{c}.742 * \\
(.313) \\
2.10 \\
\end{array}$ & $\begin{array}{c}.364^{\#} \\
(.211) \\
1.43 \\
\end{array}$ & $\begin{array}{c}.342^{\#} \\
(.211) \\
1.41 \\
\end{array}$ \\
\hline $\begin{array}{c}\text { TREATY } \\
\text { (parties signed treaty } \\
\text { to end the war) }\end{array}$ & $\begin{array}{l}2.08 * * \\
(.763) \\
8.017 \\
\end{array}$ & $\begin{array}{c}1.75^{*} \\
(.804) \\
5.76 \\
\end{array}$ & $\begin{array}{c}1.52 * \\
(.783) \\
4.58 \\
\end{array}$ & $\begin{array}{c}1.60 \\
(.947) \\
4.97 \\
\end{array}$ & $\begin{array}{c}1.70^{*} \\
(.710) \\
5.48 \\
\end{array}$ & $\begin{array}{c}1.32 \\
(.749) \\
3.76 \\
\end{array}$ \\
\hline $\begin{array}{c}\text { DEVELOP } \\
\text { (per capita electricity } \\
\text { consumption; pre-war) }\end{array}$ & $\begin{array}{c}.00057^{\#} \\
(.00036) \\
1.00 \\
\end{array}$ & $\begin{array}{c}.0006 \\
(.0004) \\
1.00 \\
\end{array}$ & $\begin{array}{c}.0008 * \\
(.0003) \\
1.00 \\
\end{array}$ & $\begin{array}{c}.0009 * * \\
(.0003) \\
1.00 \\
\end{array}$ & $\begin{array}{c}.00026 \\
(.0002) \\
1.00 \\
\end{array}$ & $\begin{array}{c}.0002 \\
(.0002) \\
1.00 \\
\end{array}$ \\
\hline $\begin{array}{c}\text { EXP } \\
\text { (Primary resource } \\
\text { exports as \% GDP) }\end{array}$ & $\begin{array}{l}-5.3^{\#} \\
(2.98) \\
.0048 \\
\end{array}$ & $\begin{array}{l}-5.85^{\#} \\
(3.33) \\
.0028 \\
\end{array}$ & $\begin{array}{l}-5.68^{\#} \\
(3.50) \\
.0033 \\
\end{array}$ & $\begin{array}{c}-7.129^{\#} \\
(4.34) \\
.0008 \\
\end{array}$ & $\begin{array}{c}-5.26^{\#} \\
(2.91) \\
.005 \\
\end{array}$ & $\begin{array}{c}-5.38^{\#} \\
(3.07) \\
.004 \\
\end{array}$ \\
\hline $\begin{array}{c}\text { DECADE } \\
\text { (0-6: decade war } \\
\text { started })\end{array}$ & $\begin{array}{l}-.349 * \\
(.174) \\
.705 \\
\end{array}$ & $\begin{array}{c}-.289 \\
(.166) \\
.748 \\
\end{array}$ & $\begin{array}{c}-.222 \\
(.186) \\
.800 \\
\end{array}$ & $\begin{array}{l}-.167 \\
(.206) \\
.845 \\
\end{array}$ & --- & --- \\
\hline $\begin{array}{c}\text { COLDWAR } \\
0=\text { war started after } \\
1989 ; 1=\text { otherwise) }\end{array}$ & --- & --- & --- & --- & $\begin{array}{c}1.56 * * \\
(.582) \\
4.76\end{array}$ & $\begin{array}{c}.995 \\
(.553) \\
2.70 \\
\end{array}$ \\
\hline Observations: & 122 & 117 & 122 & 117 & 122 & 117 \\
\hline Log-likelihood: & -45.236 & -45.357 & -45.312 & -40.993 & -57.879 & -57.603 \\
\hline Pseudo-R ${ }^{2}$ : & 0.4286 & 0.4062 & 0.3947 & 0.4187 & 0.3069 & 0.2833 \\
\hline Correctly Classified: & $85.25 \%$ & $82.91 \%$ & $86.07 \%$ & $88.03 \%$ & $80.33 \%$ & $79.49 \%$ \\
\hline Reduction in Error: & $57.46 \%$ & $51.57 \%$ & $53.31 \%$ & $58.10 \%$ & $53.97 \%$ & $53.06 \%$ \\
\hline
\end{tabular}

${ }^{1}$ Reported are: coefficients, (robust coefficient standard errors), and odds ratios in that order. $* *$

Significant at the 0.01 level; * significant at $0.05 ; 2$-tailed tests; ${ }^{\#}$ significant at $0.05 \mathrm{w} /$ one-tailed test. 
Table 3 - Hypothesis Testing with Reference to Strict Peace-Building (2 Year Period) ${ }^{2}$

\begin{tabular}{|c|c|c|c|c|c|c|c|c|}
\hline & Model A1 & Model A2 & Model A3 & Model A4 & Model A5 & Model A6 & Model A7 & Model A8 \\
\hline $\begin{array}{c}\text { WARTYPE } \\
\text { (Identity War?) }\end{array}$ & $\begin{array}{l}.109 * * \\
(-3.07)\end{array}$ & $\begin{array}{l}.129 * * \\
(-3.58)\end{array}$ & $\begin{array}{l}.131 * * \\
(-2.87) \\
\end{array}$ & $\begin{array}{l}.133 * * \\
(-3.07)\end{array}$ & $\begin{array}{l}.153 * * \\
(-3.05) \\
\end{array}$ & $\begin{array}{l}.150 * * \\
(-3.03) \\
\end{array}$ & $\begin{array}{l}.150 * * \\
(-3.15)\end{array}$ & $\begin{array}{l}.175 * * \\
(-2.86)\end{array}$ \\
\hline $\begin{array}{c}\text { LOGCOST } \\
\text { (Dead/Displaced) }\end{array}$ & $\begin{array}{l}.579 * * \\
(-3.53) \\
\end{array}$ & --- & $\begin{array}{l}.597 * * \\
(-3.36) \\
\end{array}$ & $\begin{array}{l}.618 * * \\
(-3.57) \\
\end{array}$ & $\begin{array}{l}.619 * * \\
(-3.64) \\
\end{array}$ & $\begin{array}{l}.628 * * \\
(-3.57) \\
\end{array}$ & $\begin{array}{l}.631 * * \\
(-3.73) \\
\end{array}$ & $\begin{array}{l}.641 * * \\
(-3.54) \\
\end{array}$ \\
\hline $\begin{array}{c}\text { COSTCAP } \\
\text { (Dead/dis. per capita) }\end{array}$ & --- & $\begin{array}{l}.011 * \\
(-1.93) \\
\end{array}$ & --- & --- & --- & --- & --- & --- \\
\hline $\begin{array}{c}\text { WARDUR } \\
\text { (Duration in months) }\end{array}$ & $\begin{array}{l}1.008 \\
(1.68) \\
\end{array}$ & $\begin{array}{c}1.00 \\
(1.23)\end{array}$ & $\begin{array}{l}1.009 \\
(1.71)\end{array}$ & $\begin{array}{l}1.008 \\
(1.57)\end{array}$ & $\begin{array}{c}1.00 \\
(1.46)\end{array}$ & $\begin{array}{c}1.00 \\
(1.46)\end{array}$ & $\begin{array}{c}1.00 \\
(1.48)\end{array}$ & $\begin{array}{c}1.00 \\
(1.13)\end{array}$ \\
\hline $\begin{array}{c}\text { FACTNUM } \\
\text { (Number of factions) }\end{array}$ & $\begin{array}{c}.177 * \\
(-2.49) \\
\end{array}$ & $\begin{array}{l}.137 * * \\
(-3.13) \\
\end{array}$ & $\begin{array}{c}.171 * \\
(-2.487) \\
\end{array}$ & $\begin{array}{c}.209 * \\
(-2.41) \\
\end{array}$ & $\begin{array}{c}.363 \\
(-1.64) \\
\end{array}$ & $\begin{array}{c}.338 \\
(-1.72) \\
\end{array}$ & $\begin{array}{c}.351 \\
(-1.69) \\
\end{array}$ & $\begin{array}{c}.284 \\
(-1.79) \\
\end{array}$ \\
\hline $\begin{array}{c}\text { FACTNUM2 } \\
\text { (square of factnum) }\end{array}$ & $\begin{array}{l}1.115^{*} \\
(1.89) \\
\end{array}$ & $\begin{array}{l}1.145^{*} \\
(2.48)\end{array}$ & $\begin{array}{c}1.12 * \\
(1.982)\end{array}$ & $\begin{array}{c}1.10 \\
(1.84) \\
\end{array}$ & $\begin{array}{c}1.05 \\
(0.94) \\
\end{array}$ & $\begin{array}{c}1.05 \\
(1.06) \\
\end{array}$ & $\begin{array}{c}1.05 \\
(1.03) \\
\end{array}$ & $\begin{array}{c}1.06 \\
(0.94) \\
\end{array}$ \\
\hline $\begin{array}{c}\mathrm{EH} \\
\text { (ethnic heterogeneity) }\end{array}$ & $\begin{array}{l}1.005 \\
(0.79)\end{array}$ & --- & --- & --- & --- & --- & --- & --- \\
\hline $\begin{array}{c}\text { TRNSFCAP } \\
\text { (Net curr. Transfers) } \\
\end{array}$ & $\begin{array}{l}1.003 * \\
(2.29) \\
\end{array}$ & $\begin{array}{l}1.00 * * \\
(3.09) \\
\end{array}$ & $\begin{array}{l}1.003^{*} \\
(2.33) \\
\end{array}$ & $\begin{array}{l}1.00^{*} \\
(2.41) \\
\end{array}$ & $\begin{array}{l}1.00 * \\
(2.22) \\
\end{array}$ & $\begin{array}{l}1.003 * \\
(2.25) \\
\end{array}$ & $\begin{array}{l}1.003 \\
(1.79) \\
\end{array}$ & $\begin{array}{c}1.004 * * \\
(2.58)\end{array}$ \\
\hline $\begin{array}{c}\text { UN2CINT } \\
\text { (Type of UN ops.) }\end{array}$ & $\begin{array}{l}2.048 * * \\
(2.68)\end{array}$ & $\begin{array}{l}1.72 * \\
(2.21)\end{array}$ & $\begin{array}{l}2.12 * * \\
(2.55)\end{array}$ & --- & --- & --- & --- & --- \\
\hline $\begin{array}{c}\text { UN2INT } \\
\text { (any UN action?) }\end{array}$ & --- & --- & --- & $\begin{array}{l}3.82 * \\
(2.13) \\
\end{array}$ & $\overline{---}$ & $\begin{array}{c}-- \\
\end{array}$ & --- & --- \\
\hline $\begin{array}{c}\text { UN2INT2 } \\
\text { (UN mediation) }\end{array}$ & --- & --- & --- & --- & $\begin{array}{c}.462 \\
(-0.73) \\
\end{array}$ & --- & --- & --- \\
\hline $\begin{array}{c}\text { UNTYPE5 } \\
\text { (UN enforcement) }\end{array}$ & --- & --- & --- & --- & -- & $\begin{array}{l}2.148 \\
(0.71)\end{array}$ & --- & --- \\
\hline $\begin{array}{c}\text { UNTYPE3 } \\
\text { (traditional PKO) }\end{array}$ & --- & --- & --- & --- & --- & --- & $\begin{array}{c}1.287 \\
(0.188)\end{array}$ & --- \\
\hline $\begin{array}{c}\text { UNTYPE4 } \\
\text { (multidim. PKO) }\end{array}$ & --- & --- & --- & --- & --- & --- & --- & $\begin{array}{c}22.99 * * \\
(2.87)\end{array}$ \\
\hline $\begin{array}{c}\text { TREATY } \\
\text { (treaty signed) }\end{array}$ & $\begin{array}{l}8.09 * * \\
(2.75) \\
\end{array}$ & $\begin{array}{l}5.22 * \\
(2.18) \\
\end{array}$ & $\begin{array}{l}12.42 * \\
(2.29)\end{array}$ & $\begin{array}{l}8.94 * * \\
(2.91)\end{array}$ & $\begin{array}{c}15.53 * * \\
(3.53) \\
\end{array}$ & $\begin{array}{c}14.74 * * \\
(3.53) \\
\end{array}$ & $\begin{array}{c}14.45 * * \\
(3.57) \\
\end{array}$ & $\begin{array}{c}8.367^{* *} \\
(2.58) \\
\end{array}$ \\
\hline $\begin{array}{c}\text { MILOUT } \\
\text { (military victory) }\end{array}$ & -- & --- & $\begin{array}{c}2.09 \\
(0.65)\end{array}$ & --- & -- & -- & --- & --- \\
\hline $\begin{array}{c}\text { DEVELOP } \\
\text { (p.c. electricity cons.) }\end{array}$ & $\begin{array}{c}1.00 \\
(1.64) \\
\end{array}$ & $\begin{array}{l}1.00 * \\
(2.16) \\
\end{array}$ & $\begin{array}{c}1.00 \\
(1.82) \\
\end{array}$ & $\begin{array}{c}1.00 \\
(1.87) \\
\end{array}$ & $\begin{array}{c}1.00 \\
(1.40) \\
\end{array}$ & $\begin{array}{c}1.00 \\
(1.55) \\
\end{array}$ & $\begin{array}{c}1.00 \\
(1.58) \\
\end{array}$ & $\begin{array}{c}1.00 \\
(1.84) \\
\end{array}$ \\
\hline $\begin{array}{c}\text { EXP } \\
\text { (Primary resources) }\end{array}$ & $\begin{array}{l}.0037^{*} \\
(-2.01)\end{array}$ & $\begin{array}{c}.087 \\
(-0.74) \\
\end{array}$ & $\begin{array}{c}.006 \\
(-1.65) \\
\end{array}$ & $\begin{array}{l}.003 \\
(-1.93) \\
\end{array}$ & $\begin{array}{l}.0007^{*} \\
(-2.36)\end{array}$ & $\begin{array}{c}.001 * \\
(-2.30) \\
\end{array}$ & $\begin{array}{l}.000 * \\
(-2.34) \\
\end{array}$ & $\begin{array}{l}.002 * \\
(-1.96) \\
\end{array}$ \\
\hline $\begin{array}{c}\text { DECADE } \\
\text { (decade war started) }\end{array}$ & $\begin{array}{l}.701 * \\
(-2.03) \\
\end{array}$ & $\begin{array}{l}.720 * \\
(-1.99) \\
\end{array}$ & $\begin{array}{c}.708 * \\
(-1.93) \\
\end{array}$ & $\begin{array}{l}.677 * \\
(-2.07)\end{array}$ & $\begin{array}{c}.789 \\
(-1.27) \\
\end{array}$ & $\begin{array}{c}.750 \\
(-1.68) \\
\end{array}$ & $\begin{array}{c}.749 \\
(-1.69) \\
\end{array}$ & $\begin{array}{c}.741 \\
(-1.77) \\
\end{array}$ \\
\hline Observations: & 122 & 122 & 122 & 122 & 122 & 122 & 122 & 122 \\
\hline Log-likelihood: & -44.994 & -51.504 & -44.900 & -46.473 & -48.204 & -48.324 & -48.424 & -45.648 \\
\hline Pseudo-R ${ }^{2}:$ & 0.4317 & 0.3495 & 0.4329 & 0.4130 & 0.3911 & 0.3896 & 0.3884 & 0.4234 \\
\hline
\end{tabular}

\footnotetext{
${ }^{2}$ Reported are: Odds Ratios and z-values (based on robust logistic regression w/ clustered same-country observations. ** Significant at the 0.01 level; * significant at $0.05 ; 2$-tailed tests.
} 
Table 4-Heckman Regression of Democratization with Sample Selection ${ }^{3}$

\begin{tabular}{|c|c|c|c|}
\hline $\begin{array}{c}\text { Dependent } \\
\text { Variable \& Selection }\end{array}$ & $\begin{array}{l}\text { Explanatory } \\
\text { Variables }\end{array}$ & $\begin{array}{c}\text { Model } 1 \\
\text { (distinguishes b/t } \\
\text { types of PKOs) }\end{array}$ & $\begin{array}{c}\text { Model } 2 \\
\text { (all types of } \\
\text { PKOs together) }\end{array}$ \\
\hline \multirow[t]{13}{*}{$\begin{array}{c}\text { GURR2 } \\
\text { (Democracy Index) }\end{array}$} & Constant & $\begin{array}{l}8.36^{* *} \\
(2.09)\end{array}$ & $\begin{array}{c}8.255^{* *} \\
(2.05)\end{array}$ \\
\hline & Multidimensional PKO & $4.00^{*}$ & \multirow[b]{2}{*}{---} \\
\hline & (non-traditional ops.) & (1.93) & \\
\hline & UN PKOs & \multirow[b]{2}{*}{--- } & 3.03 \\
\hline & (traditional \& multidim.) & & $(1.79)$ \\
\hline & Enforcement Mission & -3.33 & \multirow{2}{*}{$\begin{array}{l}-3.09 \\
(2.47)\end{array}$} \\
\hline & (chapter VII UN op.) & $(2.35)$ & \\
\hline & Development Level & .00032 & $\begin{array}{r}(2.47) \\
.0002\end{array}$ \\
\hline & (electricity consumption) & $(.0012)$ & $(.001)$ \\
\hline & War Duration & $.0147 *$ & $.0176^{*}$ \\
\hline & (in months) & $(.007)$ & $(.007)$ \\
\hline & 5-yr Average & $.306^{*}$ & $.298 *$ \\
\hline & Pre-War Democracy Index & $(.125)$ & $(.125)$ \\
\hline Selection & Multidimensional PKO & $1.66^{*}$ & \\
\hline Equation: & (non-traditional ops.) & $(.734)$ & --- \\
\hline PBS2L & UN PKOs & & .626 \\
\hline (Lenient PB) & (traditional \& multidim.) & --- & $(.404)$ \\
\hline & Enforcement Mission & 1.07 & 1.09 \\
\hline & (chapter VII UN op.) & $(.658)$ & $(.660)$ \\
\hline & Development Level & .0002 & .00019 \\
\hline & (electricity consumption) & $(.0001)$ & $(.0002)$ \\
\hline & War Duration & .0004 & .0007 \\
\hline & (measured in months) & $(.002)$ & $(.0023)$ \\
\hline & War Type & $-.9212 * *$ & $-.977 * *$ \\
\hline & (Identity war?) & $(.258)$ & $(.256)$ \\
\hline & Human Cost & $-.175 * *$ & $-.189 * *$ \\
\hline & (Log of dead/displaced) & $(.065)$ & $(.065)$ \\
\hline & Number of Factions & -.487 & -.531 \\
\hline & (major factions) & $(.372)$ & $(.323)$ \\
\hline & Quadratic of Number of & .012 & .0243 \\
\hline & Factions in the War & $(.038)$ & $(.030)$ \\
\hline & Net Transfers p.c. & $.0023^{*}$ & .0017 \\
\hline & (current US \$) & $(.001)$ & $(.001)$ \\
\hline & Was a Treaty Signed to & $1.01 *$ & $1.107 * *$ \\
\hline & End the war? & $(.448)$ & $(.419)$ \\
\hline & Natural Resources & $-3.41 *$ & $-3.64 *$ \\
\hline & (Primary exports \%GDP) & $(1.76)$ & $(1.72)$ \\
\hline & Dummy Variable & $.794 *$ & $.887 *$ \\
\hline & for the Cold War & $(.379)$ & $(.364)$ \\
\hline & Athrho: & $-.457 \quad(.476)$ & $-.476 \quad(.442)$ \\
\hline & Lnsigma: & $1.63 * * \quad(.101)$ & $1.651 * * \quad(.103)$ \\
\hline & Rho: & $-.428 \quad(.389)$ & $-.443 \quad(.355)$ \\
\hline & Sigma: & $(.521)$ & $(.540)$ \\
\hline & Lambda: & $-2.19 \quad(2.137)$ & $(2.008)$ \\
\hline Observations: & Censored/Uncensored: & $51 / 69$ & $51 / 69$ \\
\hline & Log-Likelihood: & -208.7298 & -210.8292 \\
\hline & Goodness of Fit: & Wald $X^{2}(5)=37.69$ & Prob $>X^{2}(5)=31.55$ \\
\hline
\end{tabular}

\footnotetext{
${ }^{3}$ Reported are: coefficients \& robust standard errors (in parentheses). ** significant at the 0.01 level; * significant at 0.05; 2-tailed tests. Model 1: Wald Test of Independent Equations $(r h o=0): \mathrm{X}^{2}(1)=0.92 \&$ Prob $>X^{2}=0.3368$. Model 2: Wald Test of Independent Equations $(r h o=0): X^{2}(1)=1.16 \&$ Prob $>X^{2}=$ 0.2816 .
} 
Table 5 - Logistic Models of Peace-building Success 2 Years after the War, Using Indices of Hostility, Local Capacities, \& International Capacities ${ }^{4}$

\begin{tabular}{c|cccc}
\hline Independent Variables & Strict PB - 2yrs & Lenient PB - 2yrs & Strict PB - 5yrs & Lenient PB - 5yrs \\
\hline Constant & $1.21^{* *}$ & $1.65^{* *}$ & $1.32^{*}$ & $1.79^{* *}$ \\
& $(.547)$ & $(.590)$ & $(.572)$ & $.624)$ \\
\hline & $-7.32^{* *}$ & $-6.59^{* *}$ & $-7.331^{* *}$ & $-6.76^{* *}$ \\
Hostility (H) Index & $(1.749)$ & $(1.53)$ & $(1.78)$ & $(1.59)$ \\
& .0006 & .0013 & .0006 & .001 \\
\hline & $3.68^{* *}$ & $2.44^{*}$ & $3.73^{* *}$ & $2.567^{*}$ \\
Local Capacity (LC) Index & $(1.359)$ & $(1.21)$ & $(1.44)$ & $(1.289)$ \\
& 39.865 & 11.580 & 42.019 & 13.03 \\
\hline & $5.73^{* *}$ & $4.42^{*}$ & $5.40^{* *}$ & $4.203^{* *}$ \\
International Capacity (IC) Index & $(2.151)$ & $(1.94)$ & $(2.17)$ & $(1.97)$ \\
& 308.696 & 83.507 & 222.475 & 66.95 \\
\hline & & & & \\
& 119 & 119 & 114 & 114 \\
\hline Observations: & -63.626 & -71.096 & -62.223 & -68.739 \\
\hline Log-likelihood: & 0.1765 & 0.1280 & 0.1644 & 0.1231 \\
\hline Pseudo-R ${ }^{2}:$ & $73.95 \%$ & $66.39 \%$ & $73.68 \%$ & $67.54 \%$ \\
\hline Correctly Classified: & $24.88 \%$ & $21.36 \%$ & $25.41 \%$ & $25.72 \%$ \\
\hline Proportionate Reduction in Error: & \multicolumn{3}{c}{}
\end{tabular}

\footnotetext{
${ }^{4}$ Reported are: coefficients, (robust coefficient standard errors), and odds ratios in that order. ** Significant at the 0.01 level; * significant at $0.05 ; 2$-tailed tests. Note: ${ }^{a}$ The possible range for the indices is from 0 to 1. ${ }^{\mathrm{b}}$ Variables are entered in the indices linearly, independently, and without weights. ${ }^{\mathrm{c}}$ Our results are robust to several different constructions of all indices. ${ }^{\mathrm{d}} \mathrm{We}$ include TREATY in the IC index b/c it is highly correlated with UN operations and in many cases, treaties were signed as a result of external involvement. ${ }^{\mathrm{e}}$ The large difference in the odds ratios of the indices is due to the differences in the actual ranges of each index. Scaling each index by its variance and re-estimating the model would adjust the odds ratios. For example, with the scaled indices as regressors, the two-year strict peacebuilding model produces odds ratios for the hostility, local capacity and international capacity indices of $.8753,1.087$, and 1.095, respectively.
} 


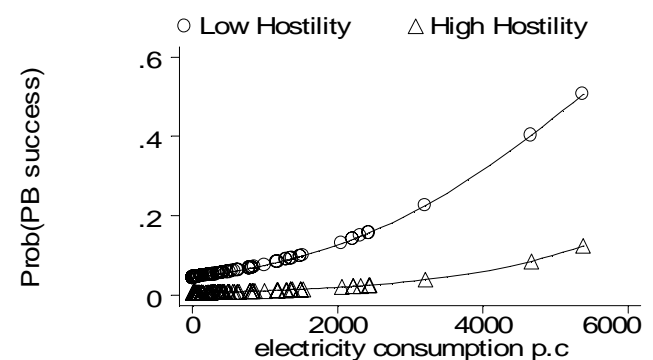

Fig.2.1: Low/High H \& Variable LC

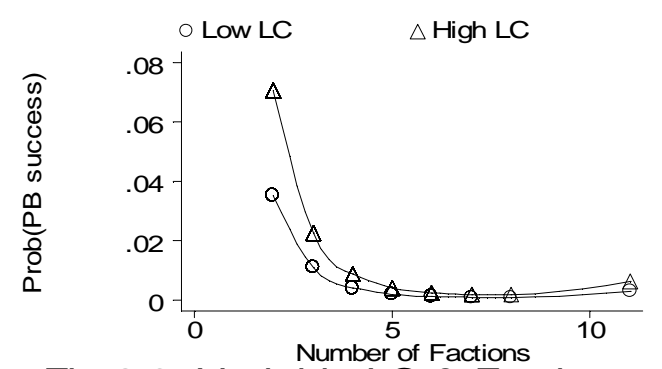

Fig.2.3: Variable LC \& Factions

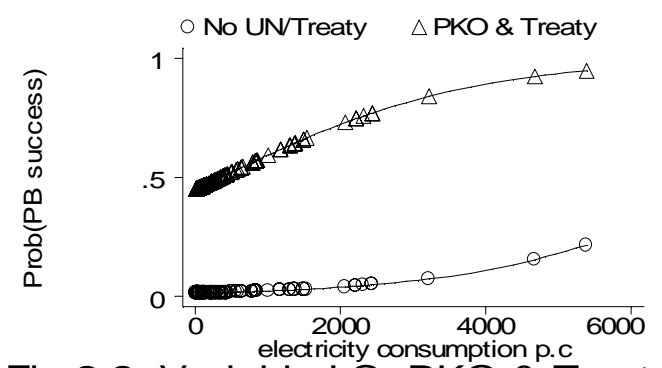

Fig.2.2: Variable LC, PKO \& Treaty

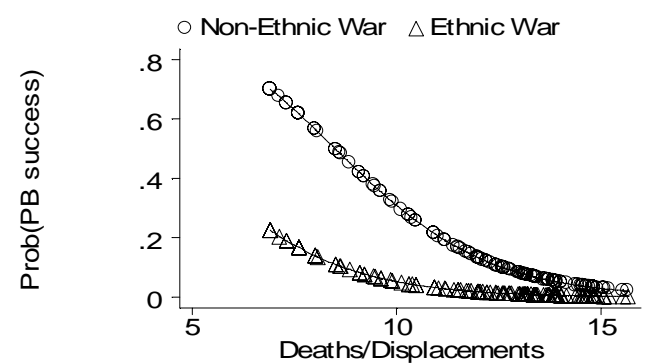

Fig.2.4: Ethnic/Non-Ethnic War

Figure 2: Comparative Statics

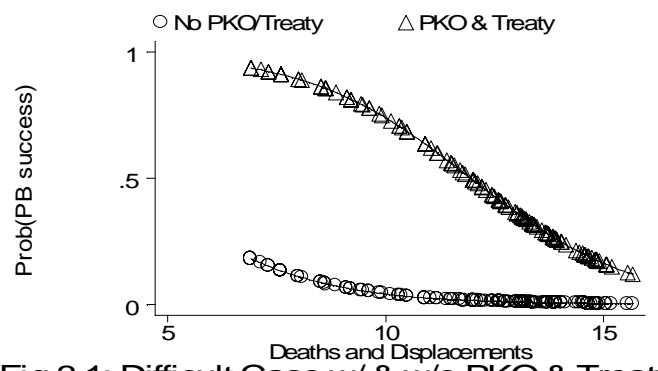

Fig.3.1: Difficult Case w/ \& w/o PKO \& Treaty

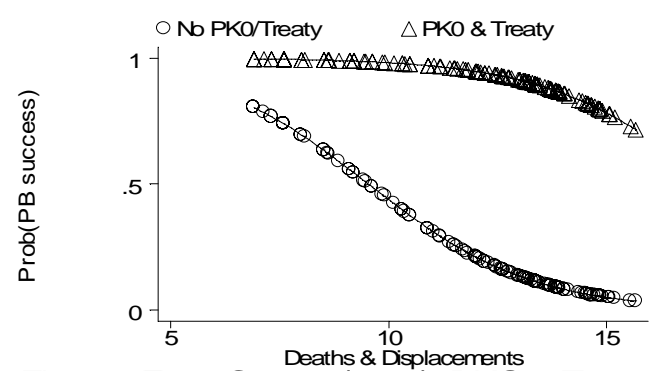

Fig.3.3: Easy Case w/ \& w/o PKO \& Treaty

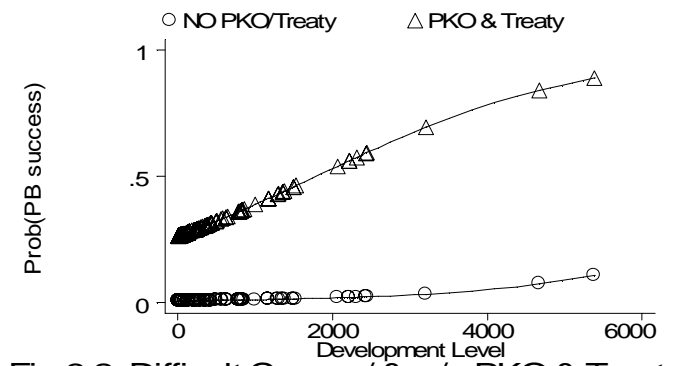

Fig.3.2: Difficult Case w/ \& w/O PKO \& Treaty

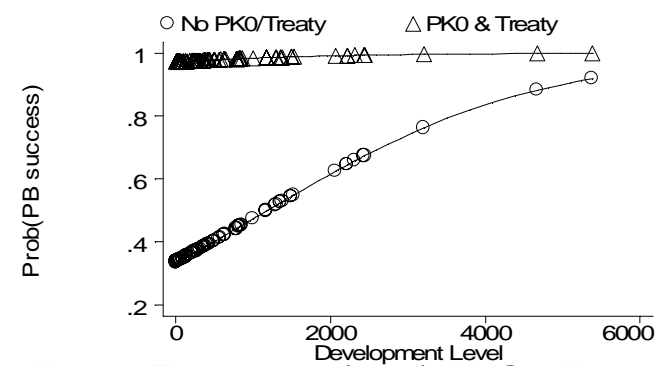

Fig.3.4: Easy case w/ \& w/O PKO \& Treaty

Figure 3: International Capacities in Peacebuilding 
" Michael W. Doyle is the Edwards S. Sanford Professor of Politics and International Affairs and director of the Center of International Studies, Princeton University, Princeton, NJ 08544, (mwdoyle@princeton.edu). Nicholas Sambanis is Economist, Development Economics Research Group, The World Bank, Washington, DC 20433 (nsambanis@ worldbank.org). The authors would like to thank Paul Collier, Michael Dark, Avinash Dixit, Ibrahim Elbadawi, Jeffrey Herbst, Ioannis Kessides, Jeffrey Lewis, Chris Paxson, Ken Schultz, Peter Singer, Erik Voeten and participants in a Center of International Studies seminar for comments on an earlier draft of this paper and the Christian A. Johnson Endeavor Foundation and the Mellon Foundation for their support.

${ }^{1}$ For a discussion of the concept, see Marrack Goulding (1993); Thomas Franck (1998); and Cousens, Kumar, and Wermester (2000). The UN's own views can be found in Boutros BoutrosGhali (1992) and Kofi Annan (1998).

${ }^{2}$ For a discussion of comprehensive peace, see Boulding (1964) and Kacowicz (1994, chapter 1). For a valuable collection of papers on peacebuilding see Cousens, Kumar, and Wermester (2000); UN Department for Development Support and Management Services and UN Industrial Development Organization (1995); and Evans (1993).

${ }^{3}$ No peace is perfect. Isaiah prophesied that we shall know peace when we see the lamb lie down with the lion. The American comedian Woody Allen has added a valuable warning for our world: one of the two might not get much sleep (Isaiah 11:6 and Woody Allen, Without Feathers, p. 28.)

${ }^{4}$ The literature is extensive. We have especially benefited from Eckstein (1964); Gurr (1993); DeNardo (1985); Lake and Rothchild (1996); and David (1997). 
${ }^{5}$ See for example, Fearon and Laitin (1996); but note that the authors are not, nor do they claim to be, explaining the empirical record of domestic peace. They acknowledge that state power and domestic authority are alternative explanations (see p.731).

${ }^{6}$ An enlightening essay is "What is Authority" (Hannah Arendt, 1961) and an insightful treatment of the Hobbesian problem applied to economic development is the concept of the "stationary bandit" (Olson, 1993).

${ }^{7}$ Not every country, however, would benefit from external mediation or intervention in its civil war. Some wars, we could argue with hindsight, are more likely to promote stable and just government if they are fought to a conclusion and the just side wins. Such an argument might be made for the US civil war.

${ }^{8}$ In Cambodia, for example, it was quite important for the prospects of peace that, together, China ceased its military support for the Khmer Rouge, the USSR and Vietnam for Hun Sen's regime, and the West for the royalist forces. Lacking that support, each of the factions found negotiations for peace more attractive.

9 Having observed peacekeeping operations in El Salvador, Cambodia, Eastern Slavonia (Croatia), Brcko (Bosnia), and Cyprus, it is our opinion that establishing a unified army or multiethnic police force, though difficult, is easy compared to agreeing on an elementary school curriculum.

10 To develop a decision-making model of peacebuilding failure we would need to make limiting assumptions about the interaction among rebel groups and between them and the government as well as about the rebels' motivation, their relative size and strength by either estimating a Cournot-Nash equilibrium (Collier and Hoeffler 2000) or Stackelberg (leadership) equilibrium (Azam 1995). The parties' decision to support peace or return to war could then be derived by maximizing their utility functions with respect to each other's expected reaction functions. 
${ }^{11} \mathrm{H}, \mathrm{LC}$, and $\mathrm{IC}$ are indices ranging from 0 to 1 (maximum). $\mathrm{IC}=\mathrm{ic}_{\mathrm{o}}+\mathrm{IC}_{1}$, where $\mathrm{IC}_{1}$ is the amount of international assistance after the war and $\mathrm{ic}_{\mathrm{o}}$ is a positive constant $\left(0<\mathrm{ic}_{\mathrm{o}}<1\right)$ representing the lowest level of international aid that is available ex ante to sovereign states, as provided by international laws ensuring that if the $\mathrm{LC}-\mathrm{H}$ does not equal zero the probability of peacebuilding success can be defined as the area of the triangle.

${ }^{12}$ Note that we use the triangle metaphor to visualize the interaction of our three core variables and we will be testing that interaction without assuming a functional form for that interaction, as we would, for example, by assuming that the peacebuilding space is only given by the area of the triangle

${ }^{13}$ There are, however, many informative and comparative case studies of peacebuilding success and failure. For a valuable critical assessment and bibliography see Collins and Weiss (1997). Among the many we have found especially helpful are Durch (1993, 1997), Licklider (1993), Brown (1996), Hampson (1996), Doyle, Johnstone and Orr, eds., (1997), Paris (1997) and Chopra (1999). Haas (1986) and Diehl, Reifschneider, and Hensel (1996) analyze the impact of UN missions on conflict recurrence focusing on interstate conflicts of varying intensity. A classic piece is Haas Butterworth and Nye (1972) who argue that the UN works best when elaborate (e.g. multidimensional) peace operations are used.

${ }^{14}$ Dropping those cases did not change the results presented in later sections. These cases are Sri Lanka (Tamil insurrection); Burundi (1991-ongoing); Angola (1992-ongoing); Colombia (post1978); and Somalia (post-1992).

${ }^{15}$ We are examining UN operations because they are the predominant form of multilateral peace operation in the entire period. But the conclusions we draw here are likely to apply to other multilateral peace operations, including some regional ones such as the NATO operation in Bosnia. 
${ }^{16}$ Briefly, we coded a peacebuilding failure if the country was at war, if it had large-scale political violence short of war, if it had divided sovereignty, or if it did not meet a minimum standard of political openness according to Gurr's democracy scores (Polity98 project). The data set, information on our coding, sources for all variables and a discussion of all war events can be downloaded at: http://www.worldbank.org/research/conflict/papers/peacebuilding.

${ }^{17}$ We dropped from our analysis wars that ended less than two years before the time of writing (see Appendix A for a full explanation).

${ }^{18}$ Both absolute and per capita measures should be important. A million casualties in Cambodia is $10 \%$ of the population; and in the US, $0.4 \%$ of the population. But with modern communications and threshold effects the political/psychological shock of a million casualties in the US is likely to be much more than $1 / 25^{\text {th }}$ the effect that it would have in Cambodia. ${ }^{19}$ There is a negative partial correlation between Human Cost (LOGCOST) and PB outcomes and a positive partial correlation between PB outcomes and War duration (WARDUR). This means that our different sign hypotheses about Human Cost and War duration are meaningful. ${ }^{20}$ See Blainey (1973) and Fearon (1995) for a similar argument which explains war occurrence at least partially as the result of uncertainty about relative capabilities and resolve.

${ }^{21}$ This hypothesis reflects similar lines of reasoning in the literature on international alliances. There are many sources; three classics are Deutsch and Singer (1964) for multipolar stability, Waltz (1964) bipolar stability, and Selten (1973) for non-monotonic factors.

${ }^{22}$ Clustering allows us to relax the assumption of independence among same-country observations. We continue to assume independence among civil wars that took place in different countries.

${ }^{23}$ For Local Capacity (LC) variables, we use proxy overall Economic development (DEVELOP) by electricity consumption per capita and we proxy Natural resource-dependence (EXP) by the share of primary exports in GDP. Data used to proxy LC are often not available before 1960, so 
we have imputed missing values in LC variables from other variables that are theoretically and empirically correlated with the LC variable in question. For example, we imputed missing observations of Economic development from data on 1960 GDP per capita, so we cannot use Economic development and GDP in the same regression.

${ }^{24}$ We created interaction terms between Cold War and the type of UN operation type, Economic development, and Identity wars, but they were not significant. We therefore report only the results of models in which Cold War is entered independently.

${ }^{25}$ We used pre-war measures of LC variables to avoid endogeneity (reverse-causality) problems and to forge a link with previous literature on civil wars, which has identified several LC variables (e.g. economic development levels) as a significant deterrent to civil war initiation. We would expect that relationship to hold for the post-war period, also, and to apply to peacebuilding processes.

${ }^{26} \mathrm{We}$ tested the robustness of our results to different sub-samples of the data by dropping highly internationalized cases of civil war; dropping cases that we coded as PB failures due to divided sovereignty; dropping cases that may be ambiguous (due to the paucity of available data); and dropping all monarchies since our strict PB variable may be biased against such political systems. Our results were generally very robust.

27 The two observations with the largest Pearson's residuals are Pakistan 1 (Bangladesh's war of independence) and Philippines 2 (MNLF). These are also the two most influential cases (in terms of influence in change in deviance), reducing our model's classification success. If we dropped these two extreme outliers, we would find all our explanatory variables highly significant (at the .05-.01 level) and the model's classification success improves. Other statistically influential cases are the Rwandan war (1990-94), Sri Lanka's ongoing war with the LTTE, the Ethiopian-Eritrean war (1974-1991), Angola's war (1975-91), and the China-Taiwan war (1947). 
${ }^{28}$ These tests include: Pearson's chi-square goodness-of-fit tests, specification link tests for each of our two single-equation models, classification tables with percentages of correctly-classified observed positive and negative outcomes, receiver operating characteristics (ROC) curves, the Hosmer-Lemeshow influence statistic, deviance statistics, Pearson's residuals, and graphs identifying outliers and their relative influence on the predicted probabilities. A technical discussion of these tests can be found in Stata (1999).

${ }^{29}$ International peacebuilding is time-sensitive in many ways. Most countries and organizations have tight deadlines and limited horizons when extending military and economic aid to other war-torn states. After two to five years, moreover, accidents (hurricanes, droughts) and other factors enter into the determinants of the stability of a country that have little to do with either the success or failure of peacebuilding strategies. Thus, we focus on the short term (2-5 years). In the longer term --i.e. 10 years or so-- our model loses much of its predictive capacity and most, though not all, key variables become non-significant, as the number of cases in our data set drops to about half the number in our 2-5-year models.

${ }^{30}$ Walter (1997) has conducted Pearson correlation tests between negotiated settlements in civil wars and different measures of war intensity, including duration and magnitude (deaths per capita) of the war and finds that they are both positively associated with the negotiation of civil wars. Our findings, however, are not comparable, since we have added cases and focus on what happens after the war rather than on negotiation of the conflict. We also use fully-specified regression models as opposed to partial correlations.

${ }^{31}$ Moreover, duration could be endogenous, if the previous conflict, or at least its length and intensity, had been caused by some failure of the major powers or the international community, then these external bodies may want to rebuild their reputation. For this they have to "signal to excess," that is, act with such force that no one lacking the full resolve for the future would go that far. (Avinash Dixit pointed out to us that this phenomenon is neatly illustrated in George V. 
Higgins's crime novel about the Boston mafia, Cogan's Trade.)

${ }^{32}$ As we anticipated, War Duration is positively correlated with human cost and with development levels. The partial correlation of War Duration and Per Capita Human Cost (COSTCAP) is 50\% higher than the correlation between War Duration and Human Cost (LOGCOST), making War Duration lose significance in Model A2 (Table 3), where we control for COSTCAP. Regan (2000) also find that civil war duration is greater in more intense wars. ${ }^{33}$ In the lenient model the quadratic term for Number of factions (FACTNUM2) loses significance when we control for Human Cost (LOGCOST). Both are proxies for hostility and they are positively correlated (28\%), which may explain the low significance level for

\section{FACTNUM2.}

${ }^{34}$ Results not reported to save space. The coefficient of UN Presence becomes .375 with standard error $=.521$.

${ }^{35}$ However, if enforcement is followed by more diversified missions, the results may be different. We only have four cases of enforcement in our data, so these results should be interpreted with caution.

${ }^{36}$ Smith and Blundell (1986). On two-stage probit models, we followed Madalla (1983), Bollen, Guilky, and Mroz (1950); Alvarez and Butterfield (2000); Alvarez and Glascow (2000); Guilkey, Mroz, and Thomas (1992); and Rivers and Vuong (1988). We used the method suggested by Rivers and Vuong to test for exogeneity by performing a t-test on the residual of the first-stage regression, included as an explanatory variable in the structural model. The residual is the fitted value of $U N$ presence (PredUN) minus the actual value of $U N$ presence (UN2INT). This procedure is used with continuous endogenous variables, so we have to assume that some added level of uncertainty is included in the residual in our case.

37 All our analysis and do-files testing the potential endogeneity of UN presence can be accessed at: http://www.worldbank.org/research/conflict/papers/peacebuilding. These regressions are not 
included in the paper since they do not change our previous results.

${ }^{38}$ The probability that the religious civil war in Algeria will result in strict peacebuilding success two years after it ends is small (.097), but has a high standard deviation (.085). That probability is even smaller for the Democratic Republic of the Congo is smaller (.042). Deploying a peacekeeping operation in the Congo would increase the probability of strict peacebuilding success to an estimated .191, with standard deviation .147 -- i.e. the $95 \%$ confidence interval for the actual probability would be between $2 \%$ and $57 \%$. To obtain these estimates, we used the "Clarify" software (Tomz, Wittenberg, King, 1999).

${ }^{39}$ We keep War Duration, Number of Factions and its quadratic at their median. 